\title{
NOVÝ PŘÍSPĚVEK KE ŠPERKAŘSKÉ PRODUKCI PRAŽSKÉ DÍLNY
}

\author{
DRAHOMÍRA FROLÍKOVÁ-KALISZOVÁ
}

\begin{abstract}
Abstrakt: Př́ výzkumu raně středověkého pohřebiště Triangl v Praze-Střešovicích byly ve dvou bohatých hrobech nalezeny exempláre šperků, které rozšiřuji rejstř̌ik dosud známých výrobki̊ pražské klenotnické dillny. Provedené chemické analýzy potvrzuji složeni výchozi suroviny totožné s některými dalšimi výrobky této dillny. Př́spěvek se zabývá také postavením těchto šperků na časové ose mezi šperkem veligradského typu a šperky z pokladĩ zlomkového stř́ibra.
\end{abstract}

Klíčová slova: 10. století - pražská dílna - kovový korálek - kaptorga - náušnice s jezdci.

A new contribution to the jewellery production of a Prague workshop

Abstract: Excavations of the early-medieval Triangle burial site in Prague-Strešovice yielded, in two rich graves, jewellery specimens that expand the repertoire of the known products of a Prague jewellery workshop. The chemical analyses confirm the composition of raw material identical to some of the workshop's other products. The paper further discusses the position of this jewellery on a timeline between Veligrad-type jewellery and jewellery from fragmented silver hoards.

Key words: 10th century - Prague workshop - metal bead - captorga - earrings with knights.

\section{Úvod}

S rozvojem výzkumů středohradištních hradišst' a pohřebišst' v 50.-60. letech 20. století narůstal také počet nálezů honosného šperku. Typickou složkou výbavy bohatých ženských hrobů jsou náušnice, jež byly označovány složeninami typu „náušnice byzantskoorientálního charakteru“ (Hrubý 1955, 228), což zároveň ukazovalo na tradičně předpokládaný původ těchto šperků (Poulík 1948, 42-56). S objevy dalších pohřebišt' a dalších bohatě vypravených pohřbů na nich se měnil i názor archeologů na jejich provenienci. V témže roce $1955 \mathrm{~J}$. Eisner píše o plodných stycích „Moravy a patrně i Slovenska s klenotniky byzantskými, kteři naučili naše řemeslníky jemnému filigránu i granulaci a obohatili jejich dílny novými tvary“, a dále o výrobcích staroměstských mistrů, dílnách staroměstských i jiných moravských a o staroměstském šperku. Zároveň již uvažuje o době, kdy tyto moravské vlivy mohly pronikat do Čech: k jejich projevu počítá knížecí hroby v Kolíně a v Želénkách, které klade do druhé poloviny 9. století. O náušnicích z hrobky v kostele Panny Marie na Pražském hradě, připisovaných manželce Spytihněva I., předpokládá, že byly již vyrobeny v pražských dílnách, stejně jako náušnice s očkem z pohřebiště u Královské jízdárny (Eisner 1955, 215-220). V roce 1966 uvádí B. Dostál, že byzantskoorientální šperk se označuje také termínem šperk staroměstského nebo veligradského rázu podle místa, kde se ho našlo nejvíce (Dostál 1966, 40-41). Postupně se ustálil pojem šperk veligradského typu (např. Staňa 1995; Galuška 2013, 99), byly nalézány i doklady místní klenotnické výroby na velkomoravských hradištích (Klanica 1974; Galuška 1989).

V Čechách jako první předpokládal místní klenotnickou produkci, vycházející z velkomoravských vzorů, M. Šolle $(1960,267)$ na základě nálezů honosného šperku objevených na pohřebišti U Libuše na Staré Kouřimi (Šolle 1966).

Znovuobjevení gombíku z hrobu v Královské zahradě Pražského hradu v depozitáŕích Národního muzea, jehož výzdoba se lišila od všech známých moravských exemplářů, avšak shodovala se s jinými gombíky z pohřebiště v Lumbeho zahradě, vedlo K. Sklenáře a J. Slámu v roce 1976 k vyslovení hypotézy o jeho výrobě v dílně působící „kdesi ve středních Čechách“ (Sklenář-Sláma 1976, 663). Badatelem, který od pouhých morfologických srovnávání přistoupil k analýzám složení kovu, byl Z. Smetánka (Smetánka-Štverák 1992). Inovativní použití meandrovitě zvlněné pásky jako konstrukčního prvku spolu s typy gombíků a zoomorfních 
náušnic $\mathrm{z}$ pohřebiště $\mathrm{v}$ Lumbeho zahradě, které nejsou z moravského prostředí známy, přivedly Z. Smetánku k formulování teze, že ,je možné, že byly zhotoveny ve středočeském regionu, patrně snad prímo v pražském centru“ $(1994,113)$. Na základě srovnávací analýzy obsahu zlata, stříbra a mědi ve 20 špercích z Pražského hradu a vybraných analogií z velkomoravských pohřebišt' konstatoval, že „hypothesa o existenci vlastni české, přesněji pražské šperkařské dílny (...) může mit i z hlediska technologického své oprávněni a překračovat již hranice hypothesy a teorie směrem k jistotě“ (Smetánka-Staňa 1996, 141). Jeho žáci při zpracování starých i nových výzkumů přicházeli s novými poznatky, které hypotézu o české, resp. pražské dílně navazující od první třetiny 10. století na šperkařství Velké Moravy a dále je rozvíjející potvrzovaly (Tomková 2005, 299; 2008, 90-93; 2011, 200; Frolík 2014, 97-104; Profantová 2013, 27-36). Ve spolupráci s Ústavem jaderné fyziky v Řeži pokračovaly analýzy složení slitin, z nichž byly šperky vyráběny (Profantová-Frána 2003; Frána-Tomková 2005, Fikrle-Frána-Tomková 2012). U všech autorů/ autorek je přijímána archeologicky doložená změna podoby ženského šperku během první třetiny 10. století v Čechách, při níž jsou typy honosných velkomoravských šperků inspirací pro výrobu obměněných typů, které se od velkomoravských předloh liší bud' výzdobnými motivy nebo přidáním nových konstrukčních prvků. Tak se na gombících objevuje motiv křriže v kruhu nebo ptáka v kosočtverci, u bubínkových náušnic vsazený štítek, u hrozníčkovitých se častěji objevuje zakončení drátu očkem a později esovitou kličkou (náušnice s „hrubozrnným“ hrozníčkem typu Jízdárna - Tomková 2012, 166). Zcela novým prvkem je použití plastického animálního motivu na záušnicích/náušnicích, nově se vyrábějí reprezentativně zdobené kaptorgy, objevují se nové typy kovových korálů, $v$ souladu s dobovým módním cítěním jsou vyráběny náušnice se třemi košíčky nebo s bubínky navlečenými na spodní oblouk. Novým ozdobným prvkem je meandrovitě skládaná páska. U jednotlivých typů se názory na to, zda jde o import z Moravy, nebo již o místní výrobek, vyvíjejí (Frolík 2014, 98). Do diskuse o produkci pražské dílny nyní mohou přispět i poznatky o špercích nalezených ve dvou hrobech z pohřebiště Triangl v Praze-Střešovicích.

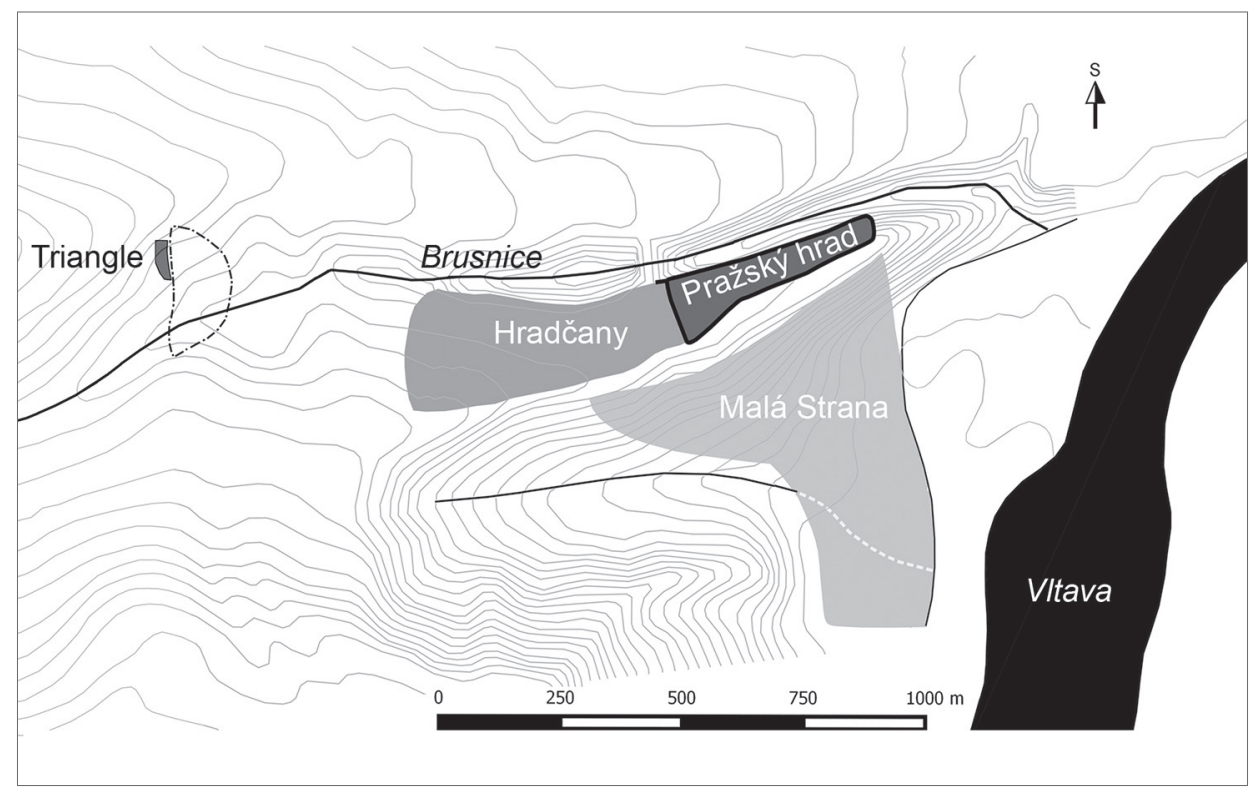

Obr. 1. Poloha pohřebiště Triangl vůči Pražskému hradu. Čerchovaně strahovská cihelna, tok Brusnice - dnešní stav. Podklad R. Brejcha, poloha cihelny podle Tomková 2006, obr. 4:1 a 5:1.

Abb. 1. Lage des Gräberfeldes Triangel gegenüber der Prager Burg. Strichpunktierte Linie Strahover Ziegelei, Wasserlauf Brusnice - heutiger Zustand. Vorlage R. Brejcha, Lage der Ziegelei nach Tomková 2006, Abb. 4:1 und 5:1. 


\section{Hroby 16 a 47 na pohřebišti Triangl}

Základní informace o pohřebišti Triangl v Praze-Střešovicích (dále jen Triangl) byly publikovány (Frolíková-Kaliszová 2014, 315-329), proto nyní stručně uvedu jen hlavní údaje. Pohřebiště leželo na jižním svahu nad údolím potoka Brusnice, který ho odděluje od ostrožny, na níž stojí Pražský hrad s předhradím Hradčany (obr. 1). Patří tedy $\mathrm{k}$ věnci pohřebišt', na nichž pohřbívali obyvatelé hospodářského zázemí Pražského hradu (Tomková-Frolík 2005, obr. 3). Bylo součástí pohřebiště ve strahovské cihelně, známého jako archeologická lokalita od 19. století, kdy byly zaznamenány nálezy kostrových hrobů $\mathrm{s}$ částečným obložením kameny a s výbavou. Popis dochovaných nálezů - tři hrnce, jedna láhev, skleněné, jantarové a polodrahokamové korálky - a záznam o nedochovaných - sekera, ostruhy - uvádí Tomková (2006, 106-114, obr. 5:3, 5:4). Antropologická analýza ukázala, že ani pohřbení muži ani ženy nevykonávali těžkou fyzickou práci a měli dostatek kvalitní stravy (Stránská 2014). Kvalitní výživu potvrdila také izotopová analýza (Frolíková-Kaliszová-Kaupová 2018). Dětský hrob 16 leží ve střední části pohřebiště, která má charakter skupinového pohřbívání, ženský hrob $47 \mathrm{v}$ jižní, s řadovým uspořádáním (obr. 2).

\section{Hrob 16 (obr. 3)}

Nálezová situace: hrobová jáma $\mathrm{v}$ půdorysu tvaru obdélníku se zaoblenými rohy, na povrchu o rozměrech $130 \times 80 \mathrm{~cm}$, stěny hrobové jámy šikmé, rovné dno o rozměrech $106 \times 56 \mathrm{~cm}$, relativní hloubka $25 \mathrm{~cm}$, orientace západ-východ $\left(260^{\circ}\right)$. Západní stěna hrobu byla šikmo protata výkopem sondy I. Borkovského, která hrob jinak neporušila. Ze zásypu byl vyzvednut zlomek bronzové jehlice (P), který se do něj dostal ze zničeného hrobu únětické kultury. V hloubce $20 \mathrm{~cm}$ se začaly mezi kostmi hrudníku vedle vláken dřeva $\mathrm{z}$ rakve objevovat modrofialově zbarvené korálky v počtu $10 \mathrm{ks}$ (A, F, G, H, I, K, N, O, Q, S), 8 drobných gombíků (B, C, D, E, Ch, J, L, M) a kaptorga (R).

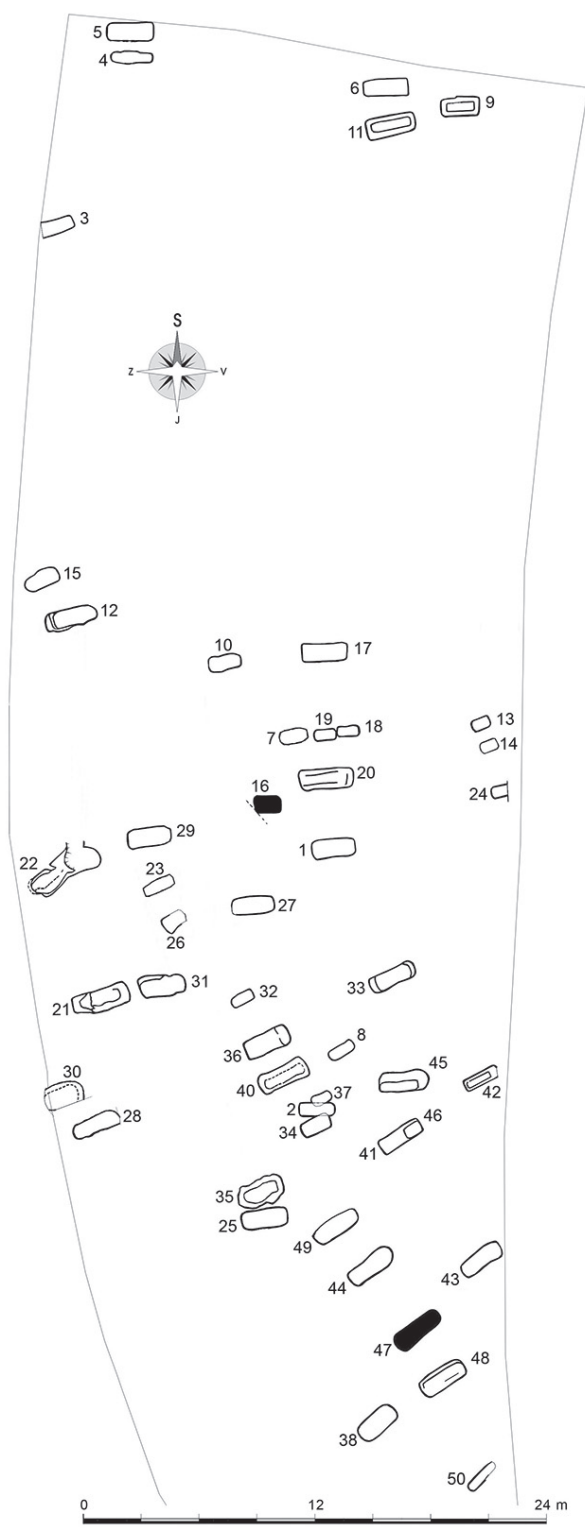

Obr. 2. Praha-Střešovice, pohřebiště Triangl. Tmavě hroby 16 a 47. Grafika D. Frolíková.

Abb. 2. Prag-Stř̌ešovice, Gräberfeld Triangel. Dunkel Grab 16 und 47. Grafik D. Frolíková. 


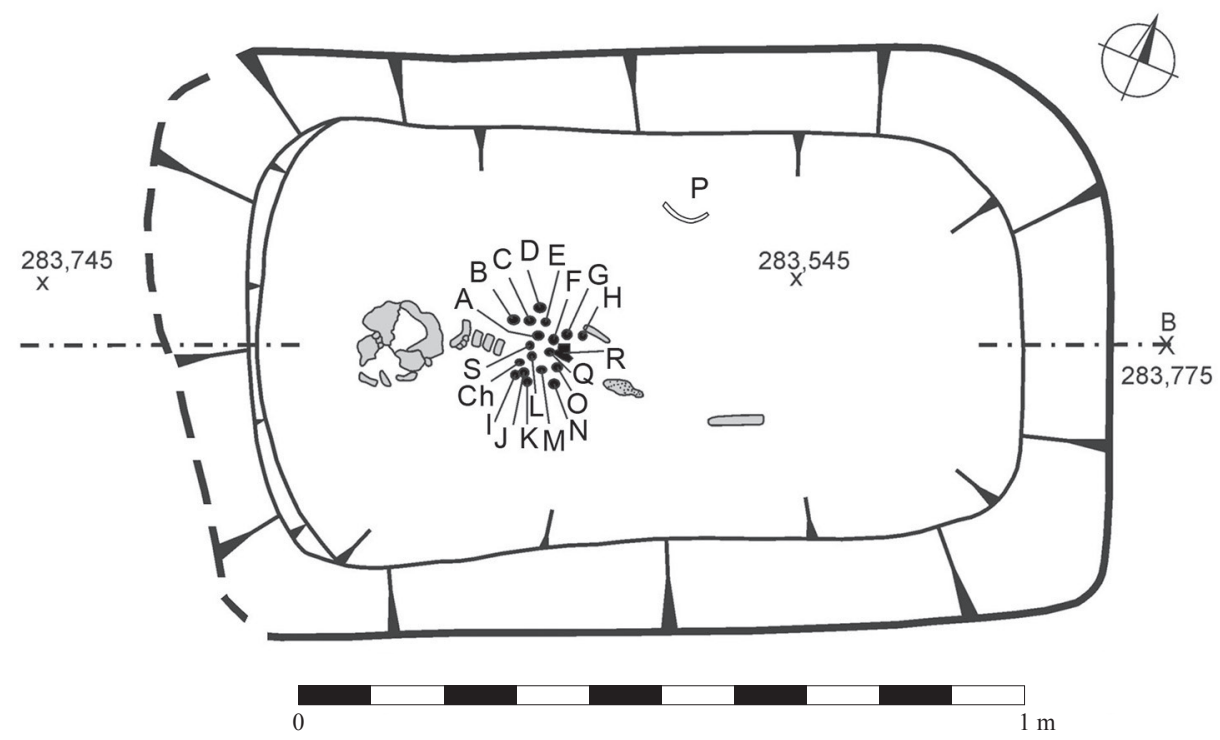

Obr. 3. Praha-Střešovice, pohřebiště Triangl. Hrob 16 s nálezy. Grafika D. Frolíková.

Abb. 3. Prag-Střešovice, Gräberfeld Triangel. Grab 16 mit Funden. Grafik D. Frolíková.

Fragmentárně zachovaná kostra dítěte ve věku 3-4 roky (Infans II - Stránská 2014, 332, tab. I) byla uložena lebkou k západu v natažené poloze, pravděpodobně na zádech.

\section{Popis nálezů (obr. 4)}

- čtyřri gombíky nezdobené (obr. 4:B, E, L, M), průměr 10,4-10,8 mm, výška s ouškem 14,8-15,7 mm;

- čtyři gombíky s hladkým pláštěm zdobeným připájenými kroužky z filigránového drátu (obr. 4:C, D, Ch, J), průměr 8,9-9,25 mm, výška s ouškem 12,6-13,5 mm;

- korálek košíčkovitý z polokoulí sestavených z tordovaných drátků stočených do šesti kroužků, spojených na vrcholech o něco větším hladkým kroužkem, lemujícím navlékací otvor, polokoule spájeny rovněž filigránovým drátem (obr. 4:H), lem navlékacího otvoru odřený od dlouhodobého nošení, průměr $11 \mathrm{~mm}$;

- tři korálky košíčkovité, z polokoulí sestavených ze tří preclíkovitě stočených dvojitých tordovaných drátků, spojených pájením, navlékací otvor zesílen tordovaným kroužkem (obr. 4:F, Q, S), průměr $10-11,2 \mathrm{~mm}$;

- šest korálků košíčkovitých z polokoulí složených ze tří preclíkovitě stočených tordovaných drátků, polokoule spojeny meandrovitou páskou a navlékací otvory lemovány kroužkem z hladkého drátu (obr. 4:A, G, I, K, N, O), čtyři z nich o průměrech 11,5-12,6 mm, dva $(K, N)$ menší o průměrech 9,5-10 mm, protažené do výšky $11-11,7 \mathrm{~mm}$, korálek K byl proveden velmi kvalitně,

1 Není zahrnut nález $\mathrm{P}$, chronologicky s pohřbem nesouvisející. 
korálek N naopak má místy rozteklou pájku slévající se s meandrovitou páskou; položeny vedle sebe působí dojmem práce mistrovské oproti učednické;

- kaptorga (obr. 4:R) dvojdílná, se samostatným víčkem, z čelního pohledu lichoběžníkovitá, z boku obdélníková, rozměry $20,5-17 \times 18,7 \times 5 \mathrm{~mm}$.

Kaptorga patří k typu IA v systému třídění podle výrobní technologie (Profantová-Šilhová 2010, 285-300). Víčko je zdobené rytým pletencem na čelní a horní straně, čelní strana vlastní schránky rytinou ptáka na puncovaném pozadí. V systému třídění podle výzdoby patří k typu s tepanou výzdobou čelní strany (typ II - Štefan 2005, 27). Pták je zachycen z boku, má zavalité tělo s malýma nožkama, malou kulatou hlavu s výrazným důlkovým okem a prohnutým zobáčkem, levé křídlo je znázorněno třemi vypnulinami, stejně tak ocas. Před zobákem ptáka se nachází nepravidelný podlouhlý útvar, zřejmě předmět, který pták drží v zobáku. Podle zavalitého těla, krátkých nohou a malé hlavy pták mohl představovat holuba/holubici držící v zobáku list. Během rytí musela být krabička vyplněna hmotou a měla nasazené víčko, nebot' pás plechu pod víčkem nese otisk pletence $\mathrm{z}$ víčka. Výplň byla po dokončení výzdoby z krabičky vyškrabována, jak o tom svědči škrábance uvnitř, pozorované i na jiných kaptorgách (např. Klecany - ProfantováŠilhová 2010, 285). Ve vzorku hmoty zevnitř kaptorgy ukázala pylová analýza pestrý výběr pylu z různých květin, který mohl pocházet ze včelího vosku. ${ }^{2}$ Otvor pro navlečení kaptorgy na šňůrku byl proražen zároveň do nasazeného víčka a těla kaptorgy, poté olemován kroužkem ze splétaného drátu, do něhož byly vsazeny granule (většina se nedochovala, možná kvůli otěru šn̆ůrkou?).

Analýzy prováděné během restaurátorských prací ukázaly, že všechny šperky z hrobu 16 byly vyrobeny ze stř́bra a jeho slitin (Frolíková-Ottenwelter-Barčáková $\mathrm{v}$ tisku). $\mathrm{Na}$ základě polohy korálků a kaptorgy je možné rekonstruovat sestavu náhrdelníku (obr. 5).
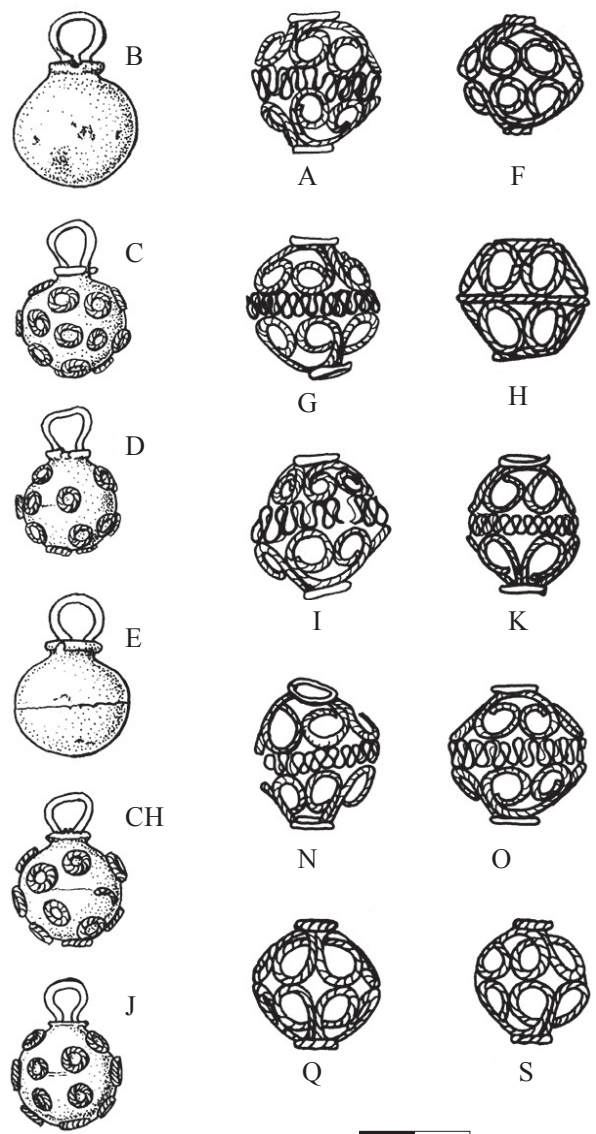

$\mathrm{O}$
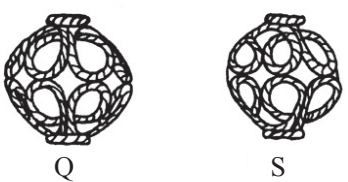

$\mathrm{S}$
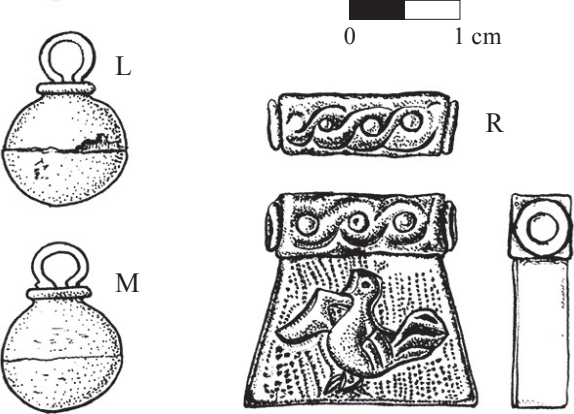

Obr. 4. Praha-Střešovice, pohřebiště Triangl. Šperky z hrobu 16. Kresba M. Housková.

Abb. 4. Prag-Stř̌ešovice, Gräberfeld Triangel. Schmuck aus Grab 16. Zeichnung M. Housková. 


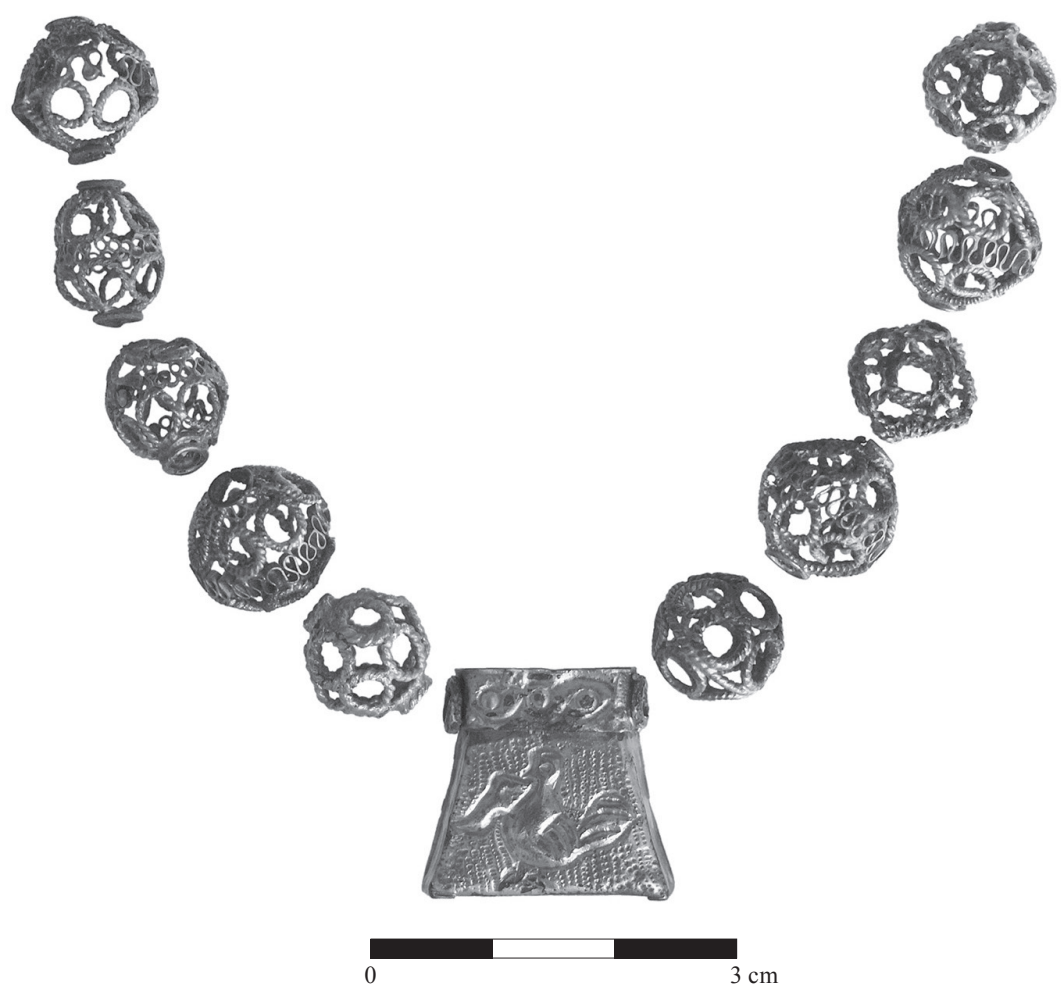

Obr. 5. Praha-Stř̌šovice, pohřebiště Triangl. Hrob 16 - náhrdelník. Foto E. Ottenwelter. Abb. 5. Prag-Stř̌ešovice, Gräberfeld Triangel. Grab 16 - Halskette. Foto E. Ottenwelter.

\section{Hrob 47 (obr. 6)}

Nálezová situace: hrobová jáma mírně lichoběžníkovitého půdorysu, se zaoblenými konci, $270 \times 95-75 \mathrm{~cm}$, uprostřed narušená vodovodní trubkou a po levé straně kořenem stromu. Orientace jihozápad-severovýchod $\left(225^{\circ}\right)$. Stěny hrobové jámy mírně zešikmené, dno o rozměrech $248 \times 81-62 \mathrm{~cm}$ klesalo od hloubky $39 \mathrm{~cm}$ za hlavou až do $48 \mathrm{~cm}$ za nohama. Lebku spolu s většinou šperků (kromě záušnice B posunuté bioturbací) jsme vyzvedli in situ a byla preparována v restaurátorské laboratoři. Po stranách mandibuly leželo celkem patnáct záušnic s očkem (I, J, H, $\mathrm{CH}, \mathrm{t}, \mathrm{s}$ vlevo, a, b, c, e, N, O, P vpravo), ${ }^{3} \mathrm{v}$ oblasti krčních obratlů celkem devět korálků (vpravo dva jantarové $S, T$ a tři skleněné $M, Q, R$, vlevo tři jantarové $C, D, F$ a jeden skleněný $E$ ), vpravo pod mandibulou, vlevo nad chybějícím ramenním kloubem, a uprostřed nad posledním dochovaným hrudním obratlem jsme našli tři figurální šperky ve zlomcích - záušnice $X$ (s odlomeným drátkem a), G a L (se zlomkem drátku K). Na článcích prstů pravé ruky byly navlečeny prsteny $(\mathrm{Z}$ a V), na levé ruce další prsten (A), po každém boku leželo torzo nože (Y, U). Záušnice a prsteny A a Z jsou stř́ibrné, prsten V měděný (Ottenwelter 2018).

Kostra ležela natažená $\mathrm{v}$ orientované poloze na znaku, paže podél těla, lebka na týlu promáčknutá dovnitř, mandibula ve zlomcích. Pohřbená byla žena, zemřelá ve věku 35-50 let (Adultus II - Maturus I - Stránská 2014, tab. I, 333).

3 Nálezy odkryté v terénu jsou označeny velkými písmeny, nálezy objevené při preparaci bloku v laboratoři malými písmeny. 


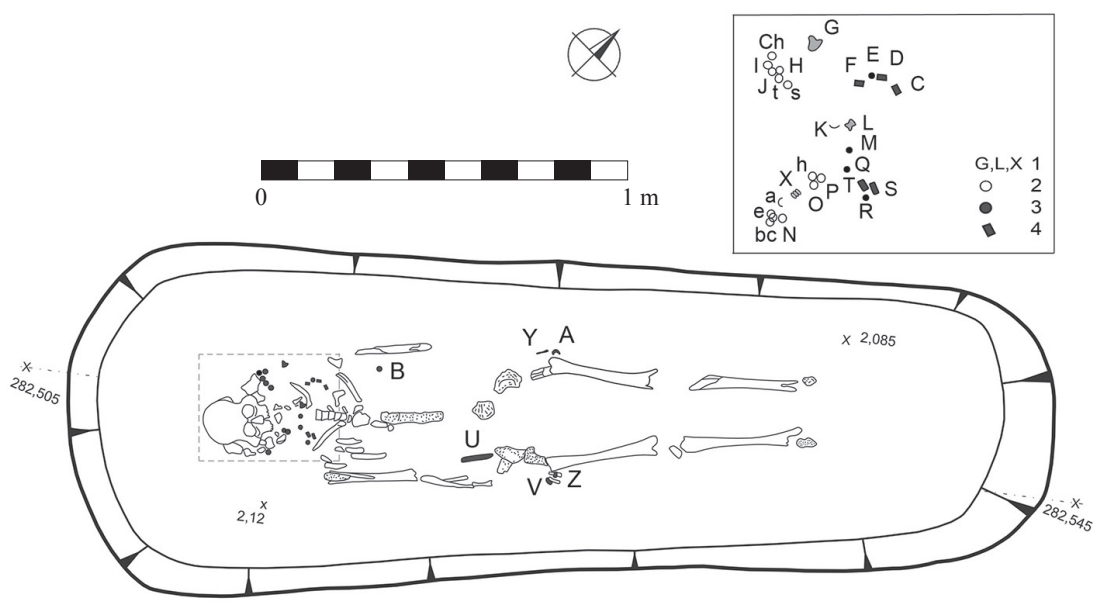

Obr. 6. Praha-Střešovice, pohřebiště Triangl. Hrob 47 s nálezy. Ve výřezu rozmístění nálezů v oblasti lebky a hrdla. 1 - záušnice s jezdci; 2 - záušnice s očky; 3 - korálky skleněné; 4 - korálky jantarové. Grafika D. Frolíková.

Abb. 6. Prag-Střešovice, Gräberfeld Triangel. Grab 47 mit Funden. Im Ausschnitt Verteilung der Funde im Bereich von Schädel und Hals. 1 - Schläfenringe mit Reiter; 2 -Schläfenringe mit Ösen; 3 - Glasperlen; 4 - Bernsteinperlen. Grafik D. Frolíková.

\section{Popis nálezů (obr. 7)}

- čtrnáct stř́brných záušnic s očkem (obr. 7:B, H-J, b-h, s, t) malých průměrů $(10,1 \times 12,1-$ $13,4 \times 14,3 \mathrm{~mm}$ ) z tenkého drátku (průměr 1,2-1,6 mm);

- tři jantarové korálky tvaru hranolu s okosenými rohy (čtrnáctistěn), s otvorem provrtaným po délce (obr. 7:C, D, poškozený F), červenohnědé, rozměry 12,3-13,4 × 10,3-12,0 × 8,8-10,0 mm;

- jantarový korálek (obr. 7:S) tvaru vysokého vícehranu s uštípanými konci, červený, $18,4 \times 11,0 \times 8,7 \mathrm{~mm}$;

-jantarový korálek (obr. 7:T) tvaru sedmistěnného hranolu, červenohnědý, 12,8 × 12,5 × 12,0 mm;

- čtyři kulaté skleněné korálky (obr. 7:E, M, Q, R) natavené na bronzové trubičce, dva modré (E, R), průměr 12 a $10 \mathrm{~mm}$; bílý $(\mathrm{M})$, průměr 7,4 mm, žlutomodrý $(\mathrm{Q})$, průměr $8,8 \mathrm{~mm}$;

- tři prsteny páskové s přeloženými konci, prsten A s podélnou rýhou, prsten V zdobený dvěma podélnými rýhami, prsten $\mathrm{Z}$ se středovým žebrem a přesekávanými okraji, průměry $18 \mathrm{~mm}$, šiřrka 3,6-4 mm;

- dva neúplné železné nože (obr. 7:Y, U), délka 79 a 55 mm, oba s dochovaným dřevem z pochvy;

- tři stř́ibrné figurálně animální záušnice (obr. 6:G, L a X; obr. 7:L, X) v podobě trojic jezdců na koni s kulatou přilbou na hlavě, zlomek drátu K patří k záušnici L, zlomek a pochází ze záušnice $X$.

4 Poznámka terminologická: problémem rozlišení náušnic jako šperku nošeného v uchu a záušnic jako šperku nošeného jiným způsobem se zabývaly hlavně polské badatelky (Musianowicz 1948-1949; Dekówna 1992; Kóčka-Krenz 1993, 41-84), u nás problém shrnula K. Tomková (2005, 226). Logicky by neměly být jako náušnice označovány ty ozdoby hlavy, které byly nalezeny v souvislosti se záušnicemi, v poloze vzdálené od lebky, ve větším počtu než dvě, tvaru ztěžujícího zavěšení v uchu (Frolíková-Kaliszová 2000, 219-220), ovšem při respektování tradičního označení honosných kusů šperku veligradského typu jako náušnic. Nálezy G, L a X proto označuji jako záušnice jak vzhledem $\mathrm{k}$ jejich tvaru a rozměrům, tak vzhledem $\mathrm{k}$ jejich počtu tří kusů a nálezové poloze. 


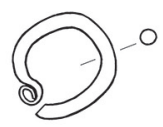

$\mathrm{t}$<smiles></smiles>

c

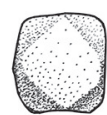

C<smiles></smiles>

B<smiles>OC1=COC=CC=C1</smiles>

$\mathrm{H}$<smiles>OC1=C=CC=COC1</smiles>

$\mathrm{Ch}$<smiles></smiles>

I<smiles>OC1=COC=CC=C1</smiles>

J

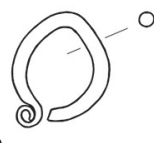

b

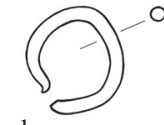

d

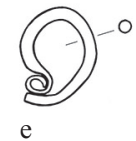<smiles></smiles>

$\mathrm{f}$<smiles>[O]c1ccccc1</smiles>

$\mathrm{g}$<smiles>[O-]c1ccccc1</smiles>

$\mathrm{h}$<smiles>C1=CC=COC=C1</smiles>

$\mathrm{s}$

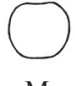

E

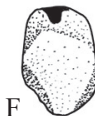

M

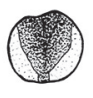

Q

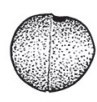

$\mathrm{R}$
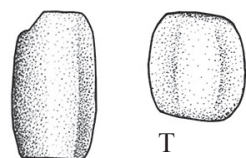

T
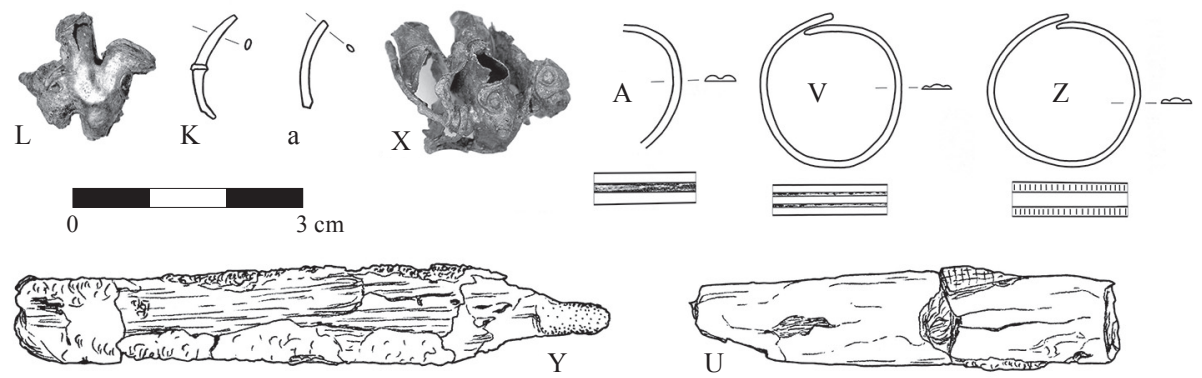

Obr. 7. Praha-Střešovice, pohřebiště Triangl. Nálezy z hrobu 47 - odkryté v terénu označeny velkými písmeny, nálezy objevené při preparaci bloku v laboratoři malými písmeny, chybí záušnice G, zachovaná v nerestaurovatelných zlomcích. Kresba V. Uramová, foto D. Frolíková.

Abb. 7. Prag-Stř̌ešovice, Gräberfeld Triangel. Funde aus Grab 47 - im Gelände freigelegte Funde mit großen Buchstaben gekennzeichnet, bei der Präparierung des Blocks im Labor entdeckte Funde mit kleinen Buchstaben gekennzeichnet, es fehlt Schläfenring G, der in nicht mehr restaurierbaren Bruchstücken erhalten blieb. Zeichnung V. Uramová, Foto D. Frolíková.

Nález G je bohužel nerekonstruovatelný, zachovaly se z něj pouze úlomky plechu, některé s natavenými drátky, největší je viditelně trojdílně členěn. Z nálezu L se zachovala téměř celá figura jezdce na koni, jeho přilba je zdobena nahoře kroužky z nataveného drátku. Ocas koně je naznačen granulí, kroužky z nataveného drátku je zdobený jeho zadek a hrud', hlava je schematizovaná na profilu do trojúhelníkovitého tvaru bez uší. Štíhlé koňské hlavičky upomínají na „myši“ na náušnici z hrobu 16 na pohřebišti v Praze - Lumbeho zahradě, které jsou však jemněji propracované a zdobené filigránem, jak to ostatně odpovídá zlaté surovině (srov. Smetánka-Frolík 2014, 65). Po bocích centrální figurky zůstaly ulomené výběžky, které ji pojily se sousedními. Nález X zachoval schéma uspořádání jednotlivých prvků do celku: na oblouku centrálního drátku byly navlečeny korpusy tří oddělených koní, z nichž je v úplnosti dochován pouze prostřední, jezdci se nedochovali vůbec. Kůn̆ měl stejnou stylizovanou hlavu bez uší, ocas naznačený granulí, zád' zdobenou dvojicí natavených drátěných kroužků. Základnu tvořil plíšek naletovaný pod nohama koní. Šlo o trojici šperků vytepaných z jedné matrice a zdobených podle jednotného záměru, což umožnilo restaurátorce-šperkařce Ludmile Barčákové rekonstruovat výrobní postup a vyrobit repliku šperku v podobě trojice rytírů na koních, navlečenou na obloukovém drátku provlečeném zadky koní, o velikosti $26 \times 23 \times 18 \mathrm{~mm}$ (obr. 8). 


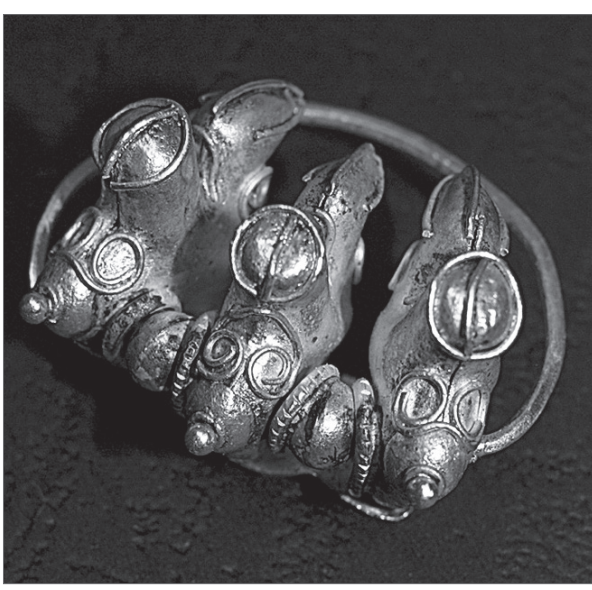

Obr. 8. Praha-Stř̌ešovice, pohřebiště Triangl. Hrob 47 replika záušnice s jezdci, vyrobená L. Barčákovou. Foto L. Barčáková.

Abb. 8. Prag-Střešovice, Gräberfeld Triangel. Grab 47 Replik des Schläfenrings mit Reitern, angefertigt von L. Barčáková. Foto L. Barčáková.

\section{Soupravy šperků z hrobů 16 a 47 z pohřebiště Triangl a chronologie}

Jednoduché páskové prsteny nebyly tak častým šperkem jako záušnice, ani nevypovídají nic o svém původu, a není proto třeba se jimi nadále zabývat. Záušnice malých průměrů $\mathrm{s}$ očkem, vyráběné $\mathrm{z}$ tenkého drátu, byly běžným produktem šperkařství konce 9. a první poloviny 10 . století a v Čechách stojí chronologicky mezi šperkem velkomoravské tradice a esovitými záušnicemi, s oběma jsou zčásti souběžné (Frolíková-Kaliszová 2000, 239; Profantová 2011, 151-157; Frolík 2014, 45-47). Záušnice z hrobu 47 tedy nemusely být vyrobeny právě v pražské dílně (i když podle složení slitiny mohly); jsou však nejlepším vodítkem pro archeologické datování souboru šperků z hrobu 47. Naopak tzv. zoomorfní či animální náušnice jsou pokládány za typický výrobek české, resp. pražské dílny (naposledy Profantová 2013, 28; Frolík 2014, 98). V případě hrobu 47 je namístě spíše název figurálně animální záušnice, a to vzhledem $\mathrm{k}$ jejich tvaru. Byly vyrobeny z ternární slitiny $\mathrm{Ag}+\mathrm{Cu}+\mathrm{Au}$ s převahou stříbra (přes 90 \%), tepáním každé strany ze stř́ibrného plechu na matrici a následným spájením (Ottenwelter 2018).

Zavěšení takového rozměrného šperku je představitelnější na pásce, v lemu látky, případně $\mathrm{v}$ pletenci vlasů než př́ímo v uchu jako náušnice. Na základě terénního nálezu rozmístění trojice šperků se jako nejpravděpodobnější způsob nošení jeví představa, že zdobily a/nebo spínaly okraje závoje/šátku vdané ženy na ramenou a pod bradou. Soubor z hrobu 47 je tak datován na jedné straně dobou výroby záušnic s očky, a na druhé straně přítomností náhrdelníku z jantarových a jednoduchých skleněných korálů, který je typický pro druhé dvě třetiny 10. století (Tomková 2008, 97). Vzhledem k této kombinaci je možno pohřeb klást do druhé třetiny 10. století. Datování AMS $\mathrm{C}^{14} \mathrm{z}$ kostního kolagenu kosti lýtkové poskytlo s pravděpodobností 83,2 \% kalibrované datum v intervalu 861-972, což archeologickému datování neodporuje (obr. 9, vzorek 19_535; SvětlíkŠneberger 2020). ${ }^{5}$

V hrobě 16 se nenašel dobře datovatelný předmět typu záušnic, nezdobené i jednoduše zdobené gombíky byly vyráběny $\mathrm{v}$ širokém časovém intervalu od staršího velkomoravského horizontu (Ungerman 2005, obr. 2; Galuška 2013, 235) až do poloviny 10. století (Chorvátová 2009, 17). Vzhledem k relativně jednotnému vzhledu, velikosti a materiálu gombíků z hrobu 16 sice můžeme předpokládat, že byly vyrobeny v jedné dílně, a to pražské (Frolíková-Ottenwelter-Barčáková v tisku), avšak nejde o specifický produkt této dílny, proto není třeba se jimi dále zabývat. Kaptorgy jako schrány na amulety byly každá jedinečná svou výzdobou, i když nikoliv výrobním postupem. Jakožto jednotliviny nejsou přesněji datovatelné, jejich chronologické zařazení se odvíjí od datování hrobu, př́ípadně jen od datování pohřebiště. Kovové korálky z hrobu 16 samy o sobě rovněž nejsou přesněji datovatelné, avšak skýtají možnost sledovat vývoj tvarů vyráběných v pražské dílně. Se stanovením horní hranice uložení pohřbu tak pomáhá jen datování $\mathrm{AMS} \mathrm{C}^{14} \mathrm{z}$ kostního kolagenu z lebky, které poskytlo s pravděpodobností 95,4 \% kalibrované datum v širokém intervalu 774-950 AD. Srovnáním s archeologickým datováním se jako odpovídající jeví menší hrot objevující se v časovém rozmezí 921-950 (obr. 9, vzorek 19_535; Světlík-Šneberger 2020).

5 Vzorky zpracovávala Radiouhlíková laboratoř CRL při ÚJF a ARÚ Praha. 

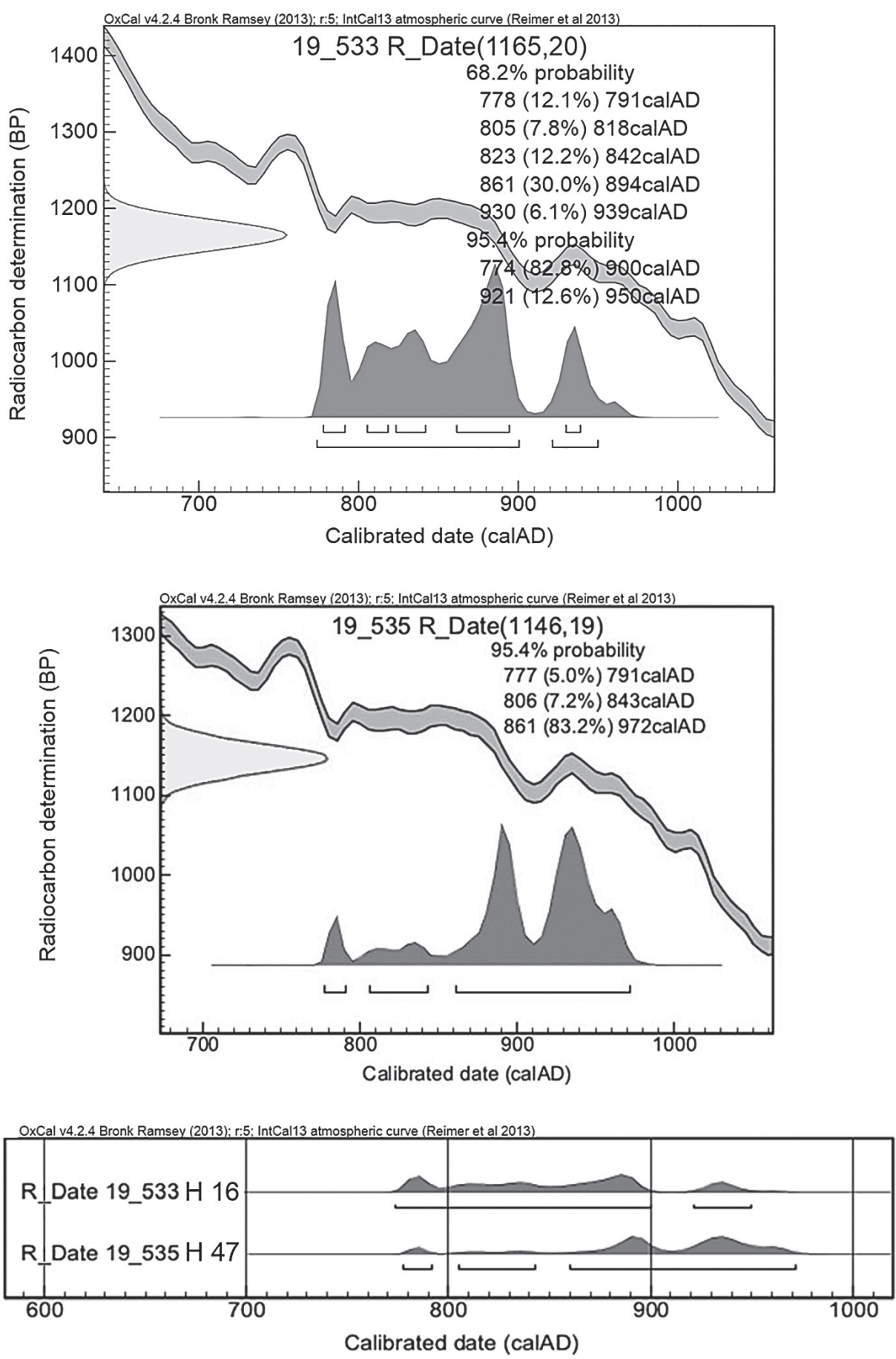

Obr. 9. Diagramy datování $C^{14} \mathrm{z}$ kostního kolagenu. Podle Světlík-Šneberger 2020.

Abb. 9. Diagramme der $\mathrm{C}^{14}$ Datierungen aus Knochenkollagen. Nach Světlík-Šneberger 2020. 


\section{Časoprostorové vztahy šperků z produkce pražské dílny nalezených v hrobech na pohřebišti Triangl}

Meandrovitá páska je prvkem převzatým z karolínského šperkařství (Profantová 2013a, 209), avšak do českého prostředí se dostala prostřednictvím velkomoravského klenotnictví - nejstarším nálezem je pár dvoupláštových gombíků z hrobové výbavy „kněžny“ ze Želének, které byly vyrobeny v mikulčické šperkařské dílně (Smetánka 1994; Profantová-Militký 2000; Profantová 2013a, 209). Zatímco na dvoupláštových gombících z mikulčické dílny byla meandrovitá páska použita jako jeden z výzdobných prvků, na dvoupláštových gombících z hrobu 16 z Prahy - Lumbeho zahrady (Ottenwelter-Děd-Barčáková 2014, 165-167) přistupuje k funkci zdobné i funkce konstrukční, nebot' vnější plášt' gombíků je tvořen meandrovitými
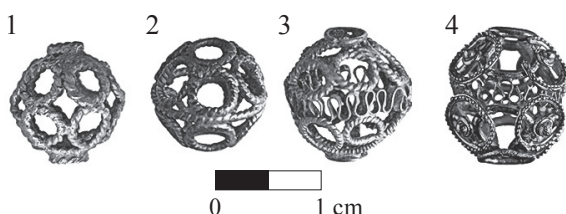

Obr. 10. Typy košíčkovitých korálků z pražské dílny: 1 - korálek ze sletovaných polokoulí; 2 - korálek z polokoulí spojených tordovaným drátkem; 3 - korálek z polokoulí spojených meandrovitou páskou; 4 - ,patentkovitý“ korálek; 1-3 - košíčkovité korály z hrobu 16 z Prahy-Střešovic, pohřebiště Triangl; 4 - korál z hrobu 100 z Prahy - Lumbeho zahrady. Foto 1-3 E. Ottenwelter, 4 podle Barčáková 2014.

Abb. 10. Typen der körbchenartigen Perlen aus der Prager Werkstatt: 1 - Perle aus zusammengelöteten Halbkugeln; 2 - Perle aus mit tordiertem Draht verbundenen Halbkugeln; 3 - Perle aus mit meanderförmigem Band verbundenen Halbkugeln; 4 - ,druckknopfartige“ Perle; 1-3 - körbchenartige Perlen aus Grab 16 aus Prag-Střešovice, Gräberfeld Triangel; 4 - Perle aus Grab 100 aus dem Prager Lumbe-Park. Foto 1-3 E. Ottenwelter, 4 nach Barčáková 2014. páskami na jeho povrchu. Právě tento posun funkce byl pro Z. Smetánku jedním z důvodů, pro něž považuje šperky z hrobu 16 z Prahy - Lumbeho zahrady za výrobek místní pražské dílny (Smetánka 1994, 111-113). Na košíčkovitých korálcích z hrobu 16 z pohřebiště Triangl je meandrovitá páska použita především jako konstrukční prvek spojující polokoule košíčků, který je však zároveň mnohem zdobnější než spojení pouhým pájením nebo drátkem po obvodu (obr. 10:1-3). Stejným způsobem byla použita také na čtyřech korálcích z hrobu 100 dospělé ženy z pohřebiště v Praze - Lumbeho zahradě (Smetánka-Frolík 2014, 169-171). Košíčky těchto korálků mají zcela odlišné, originální pojetí a složitou konstrukci (obr. 10:4): každou polokouli tvoří dvojice silnějších zkroucených drátků, na nichž je posazeno po dvou malých kroužcích z hladkého drátu, celkem osm malých kroužků je zdobeno připájeným kroužkem ze zrnitého drátu. Ve středu drobných kroužků je velká granule, která zároveň pojí nosné zkroucené drátky. Polokoule jsou spojeny meandrovitou páskou a navlékací otvory lemovány kroužkem ze silného hladkého drátu ${ }^{6}$ (Ottenwelter-Děd-Barčáková 2014, 233-236).

Zajímavým př́ípadem jsou náušnice s řetízky a meandrovitou páskou z hrobu 33 z 10. století z Niedermünsteru u Řezna (Profantová 2013a, obr. 2). N. Profantová připouští dvě alternativní možnosti jejich původu: bud' místní, bavorský, nebo naopak původ v pražské dílně, přičemž by pohřbená žena zřejmě pocházela z Čech (Profantová 2013a, 212). Meandrovitě vinutá páska se později vyskytuje na některých typech šperků, zejména náušnicích typu Obra (Kóčka-Krenz 1993, 77, 80) objevujících se od druhé poloviny 10. století v Polsku a Polabí, známých jednak z depotů druhé poloviny 10. až 11. století, např. Obra Nowa (Slaski-Tabaczyński 1959, tab. 14), Sejkowice (Gupieniec-Kiersnowscy 1965, tab. 18), Niederlandin (Schulze-Dörlamm 1992, 170-171), jednak z pohřebišt', např. Oberwellenborn (Spazier-Seidl-Schenk 2015, 186-188), Bodelwitz (Schulze-Dörrlamm 1992, 139). Jejich předlohy jsou hledány právě v českém prostředí (Spazier-Seidl-Schenk 2015, 193).

Kovové korálky z hrobu 16 skýtají možnost sledovat vývoj tvarů vyráběných v pražské dílně. Ideovým zdrojem výroby filigránových korálků byly velkomoravské košíčkovité náušnice. Technologie výroby korálků z pražské dílny je stejná: filigránní drátek je tvarován do preclíčků (též brýlovitých tvarů - Hrubý 1955, 240) nebo kroužků (Poulík 1975, tab. 53:3-5), ty jsou pak

6 Výsledný vzhled připomíná soustavu patentek. 
spájeny do dvou polokoulí. Od košíčků náušnice je odlišuje lemování obou vrcholových-navlékacích otvorů filigránním nebo hladkým drátkem (Tomková 2005, 243) a větší velikost otvoru kvůli provlečení šňůrky nebo řetízku (technická informace restaurátorky a šperkařky L. Barčákové). Korálky z polokoulí spojených pouze pájením mají analogie na pohřebištích Pražského hradu: byly spojovacím prvkem řetězu, na němž visely dvě kaptorgy v hrobě 82 z Prahy - Lumbeho zahrady (Smetánka-Frolík 2014, 148; Ottenwelter-Děd-Barčáková 2014, 236, obr. 4:41), stejný typ byl nalezen i v hrobě 2/82 na pohřebišti v Praze - Za Jízdárnou (Tomková 2006, 50, obr. 2:16), patří $\mathrm{k}$ němu zřejmě i polovina korálku nalezená v hrobě 73/51 na tomtéž pohřebišti (Tomková 2006, 38, obr. 2:11). Zlomek stř́brného košíčkovitého korálku rovněž z kroužků z filigránního drátu byl nalezen v hrobě 14 na pohřebišti Klecany II (Profantová 2011, 140-141; 2010, tab. 91:2). N. Profantová je klasifikuje jako typ VII a ve svém soupisu uvádí vedle vyjmenovaných ještě ztracené korálky z Prahy - Bartolomějské ulice a tři korálky z hrobu 20 na pohřebišti v Bášti (Profantová 2011, tab. 12:4). Košíčkovité korálky můžeme seřadit do typologické řady od korálků z polokoulí spojených pájením (obr. 10:1) přes korálek z polokoulí spojených drátkem (obr. 10:2) po korálky z polokoulí spojených meandrovitou páskou (obr. 10:3, 4). Považujeme-li za nejpravděpodobnější dobu pohřbu dítěte z hrobu 16 na pohřebišti Triangl druhou čtvrtinu 10. století (ante quem 950), můžeme výrobu těchto korálků klást do první poloviny 10. století. Datování potvrzuje hrob $2 / 82$ z pohřebiště v Praze - Za Jízdárnou, v němž byla pohřbena žena stáŕí maturus II. V prvotní publikaci byl její pohřeb kladen do první poloviny 10. století na základě kombinace součástí jejího náhrdelníku: vedle korálků typu A byla jeho součástí malá stř́ibrná kaptorga typu typu IA zdobená vegetabilním motivem na puncovaném pozadí a jantarové a skleněné korálky (Frolík-Tomková-Žegklitz 1988, 437-438). Nově se připouští i datování „do doby o trochu pozdějši" (Tomková 2005, 244). Náhrdelník z hrobu 2/82 z pohřebiště v Praze - Za Jízdárnou je tedy složen z prvků vyskytujících se v náhrdelnících z obou pojednávaných hrobů z pohřebiště Triangl.

Kaptorgám byla v posledních letech věnována značná pozornost (Štefan 2005; ProfantováŠilhová 2010; Profantová-Špaček-Novotná 2011). Způsob konstrukce lichoběžníkovitých kaptorg ze dvou částí a čtyř plechů, popsaný v polské literatuře (trapézovité kaptorgy - Kóčka-Krenz
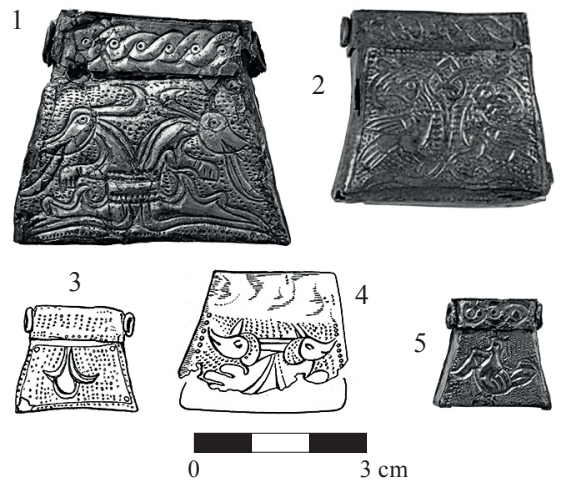

Obr. 11. Kaptorgy z pražské dílny. 1 - Klecany II, H 22; 2 - Hostivice-Palouky, H 2103; 3 - Pražský hrad - Za Jízdárnou, H 2/82; 4 - Pražský hrad - Lumbeho zahrada, H 117; 5 - Praha-Střešovice, pohřebiště Triangl, H 16. Podle Profantová-Daněček, obr. 2; Tomková 2006, obr. 2:16; Frolík-Smetánka 2014, 192. Foto 1 a 5 E. Ottenwelter.

Abb. 11. Kaptorgen aus der Prager Werkstatt. 1 - Klecany II, H 22; 2 - Hostivice-Palouky, H 2103; 3 - Prager Burg - Hinter der Reitschule, H 2/82; 4 - Prager Burg - Lumbe-Park, H 117; 5 - Prag-Střešovice, Gräberfeld Triangel, H 16. Nach Profantová-Daněček Abb. 2; Tomková 2006, Abb. 2:16; Frolík-Smetánka 2014, 192. Foto 1 und 5 E. Ottenwelter.
1993, 86), byl potvrzen na př́kladech nálezů z pohřebiště v Lumbeho zahradě Pražského hradu (Ottenwelter-Děd-Barčáková 2014, 252-253) i u kaptorgy z hrobu 22 z pohřebiště Klecany II (obr. 11:1) a u kaptorgy z hrobu 2103 z Hostivic-Palouků (obr. 11:2; Profantová-Daněček 2017). Všechny jsou datovány do 10. století. K nejstarším českým kaptorgám můžeme počítat kaptorgu z hrobu „kněžny“ z Kolína z poslední třetiny 9. století (Profantová-Šilhová 2010, 295). Lichoběžníkovité kaptorgy výrobního typu IA (ProfantováŠilhová 2010, 300) jsou v Čechách nejčastější. Bývají zdobeny bud' geometrickou výzdobou z filigránového drátu a granulace (Štefan 2005, 25, autor k nim však počítá i kaptorgy technologického typu IB podle N. Profantové), nebo rytou výzdobou na puncovaném pozadí (Štefan 2005, 27). Motiv pletence na víčku a puncované pozadí motivu na čelní straně jsou společné kaptorgám z pohřebiště na Trianglu, z Klecan II, z Prahy - Lumbeho zahrady (obr. 11:4) a Hostivic, které byly vyrobeny analogickým postupem, avšak liší se hlavním 
výzdobným motivem. Zatímco na kaptorgách z hrobu 117 z Prahy - Lumbeho zahrady a z hrobu 22 na pohřebišti Klecany II je vyobrazena dvojice afrontovaných zvířat (Smetánka-Frolík 2014, 192; Profantová 2010, tab. 94), na kaptorze z hrobu 2103 z Hostivic vidíme dvojici afrontovaných ptáků (Profantová-Daněček 2017, 96, obr. 2:10), na kaptorze z hrobu 16 z pohřebiště Triangl je zachycen samostatný pták (obr. 11:5) a na kaptorze $\mathrm{z}$ hrobu $2 / 82 \mathrm{z}$ pohřebiště $\mathrm{v}$ Praze $-\mathrm{Za}$ Jízdárnou (obr. 11:3) je pouze drobný vegetabilní motiv a navíc její víčko je pouze důlkované (Tomková 2006, obr. 2:16). Motiv ptáka se často vyskytuje na velkomoravských gombících, objevil se i na páru měděných pozlacených gombíků z hrobu 84 v Praze - Lumbeho zahradě (Smetánka-Frolík 2014, 152-154). Výrobní stopy svědčí o výrobě v jedné, patrně pražské dílně (Smetánka-Frolík 2014, 99; Profantová-Daněček 2017, 101; Frolíková-Ottenwelter-Barčáková v tisku), a současně o snaze tamních klenotníků individualizovat každý kus. Domnívám se, že to bylo v souladu s účelem kaptorgy jako schránky na amulet: v našem prostředí byl amulet jakožto prostředek magické ochrany určen pro jednotlivce, který ho měl nosit, at' už za účelem ochrany nebo uzdravení. Schránka ze stř́ibra i její výzdoba mohly magickou sílu amuletu posilovat (Sztyber 1999, 284-285).

Magickou funkci připisuje A. Sztyber také záušnicím s motivem koní (Sztyber 1999, 285), k nimž patř́ i záušnice s jezdci z hrobu 47 z pohřebiště Triangl. Nejsou prvním nálezem svého druhu, nejstarším byla záušnice $z$ Lovosic, dnes ztracená. Na reprodukovaném vyobrazení (obr. 12:1; Profantová 2013, obr. 4:5) vypadá kůň s jezdcem stejně jako zachovalá část záušnice $\mathrm{L}$ z pohřebiště Triangl, obě záušnice tak mohly být produktem stejné dílny, což ovšem zůstane jen v rovině domněnky. Dalším podobným nálezem je záušnice z Hořejan, na níž je trojice rytírư na koních sestavená podle identického schématu (obr. 12:2; Kabát 1950). Drát však má provlečený středem koňských těl, ukončený esovitou kličkou (původní ukončení esovitou kličkou ovšem nelze vyloučit ani u stř̌š̌ovických exemplářů), přilbice rytírư i těla koní jsou zdobeny tordovanými drátky (Profantová 2013, obr. 4:6), nikoliv kroužky z hladkého drátu, a hlavně koním chybí nohy, jejich těla jsou posazena rovnou na podložní plíšek. Tento nález lze datovat pouze v rámci 10. století a jeho spojení s pražskou dílnou je nejisté. Mnohem častěji se objevuje motiv koně nebo koní bez jezdce. Ojediněle realistickým zpodobením koně se vymyká pár bubínkových záušnic s řetízky z hrobu 106b ze Staré Kouřimi (Šolle 1966, obr. 40b). Běžnější jsou koňské busty na kaptorgách, např́íklad dvojice torbičkovitých kaptorg s trojicí koní z téhož hrobu 106b (obr. 12:4). Silně stylizovaná jsou zvířata (koně?) na záušnici z Niedermünsteru (obr. 12:8). Uši ztvárněné kroužkem se objevují na zoomorfních záušnicích z hrobu 16 v Praze - Lumbeho zahradě (obr. 12:3), na kaptorze z hrobu 53 tamtéž, na kaptorze z hrobu 2 z pohřebiště v Praze na Václavském náměstí (Huml-Starec 1994, obr. 4) a na kaptorze z hrobu 268 z Libice (Princová-Justová 1997, obr. 2). Všechny nálezy jsou datovány do první poloviny 10. století (Profantová 2013, 28; Smetánka-Frolík 2014, 71). Z téže doby by mohla pocházet i animální plastika z hrobu 2/3 z pohřebiště v Matzhausenu poblíž Řezna (obr. 12:9), tradičně datovaného do 9. století (Neumayer 2000a, 192-193). Po nejnovějším rozboru nálezových okolností i analýzách šperků během jejich restaurování je datování hrobu a potažmo celého pohřebiště zpochybněno právě s ohledem na podobnosti s produkcí pražské dílny (Hasil-Ottenwelter-Barčáková 2019, 11). Zoomorfní motiv většinou interpretovaný jako zobrazení více či méně stylizovaných koní nacházíme i na mladších nálezech, většinou $z$ depotů stříbra z konce 10. až 11. století, například na špercích z depotu z Čistěvsi (obr. 12:5) a analogických náušnicích z depotu z Radzikówa v Malopolsku (obr. 12:6; Haisig-Kiersnowski-Reyman 1966, tab. 12), na kaptorze z depotu v severoněmeckém Marlow (obr. 12:7; Herrmann 1985, Taf. 71a), na kaptorze z Wielonku ve Velkopolsku (SlaskiTabaczynski 1959, tab. 23), na náušnicích s řetízky z hornolužického Meschwitz (obr. 12:11, Richthofen 2016, Abb. 1). Rytír na koni držící štít z depotu z Lisówku (Neumayer 2000, 165), datovaný do první čtvrtiny 11. století, stejně jako drobná zvířecí plastika z depotu z Komárova,

7 O původu a významu motivu ptáka viz Klanica 1970, 440-442; 1991; Anoškinová 1995; Profantová 1996, 33; Charvát 2010, 19-23; Profantová-Daněček 2017, 107-111; Frolíková-Ottenwelter-Barčáková v tisku. 

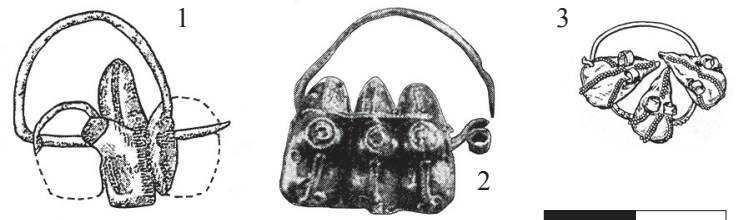

4
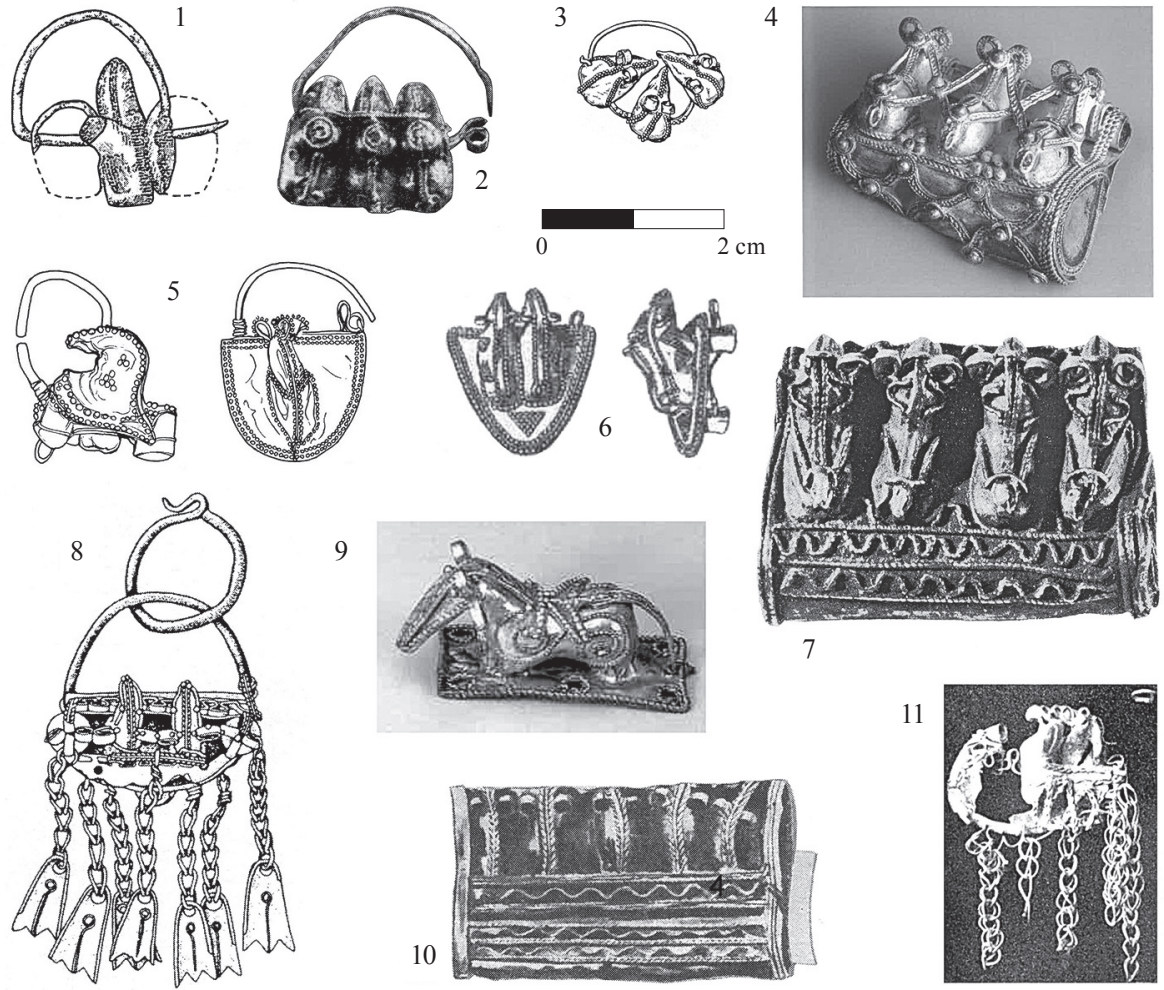

7

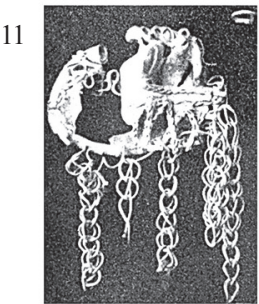

Obr. 12. Zoomorfní šperky 10.-11. století. 1 - Lovosice; 2 - Hořejany; 3 - Pražský hrad - Lumbeho zahrada; 4 - Stará Kouřim; 5 - Čistěves; 6 - Radzików II; 7 - Marlow; 8 - Niedermünster; 9 - Matzhausen; 10 - Dziernica; 11 - Meschwitz; 4, 6, 7, 9-11 bez měřítka. Podle Profantová 2013, obr. 4:2, 5, 6; 2000, 215; Frolík-Smetánka 2014, 65; Polanský-Tomková 2006, obr. 9c; Neumayer 2000, 193; Slaski-Tabaczyński 1959, tab. IV; Herrmann 1985, Taf. 71a; Richthofen 2016, Abb. 1.

Abb. 12. Zoomorpher Schmuck 10.-11. Jahrhundert. 1 - Lovosice; 2 - Hořejany; 3 - Prager Burg - Lumbe-Park; 4 - Stará Kouřim; 5 - Čistěves; 6 - Radzików II; 7 - Marlow; 8 - Niedermünster; 9 - Matzhausen; 10 - Dziernica; 11 - Meschwitz; 4, 6, 7, 9-11 ohne Maßstab. Nach Profantová 2013, Abb. 4:2, 5, 6; 2000, 215; Frolík-Smetánka 2014, 65; Polanský-Tomková 2006, Abb. 9c; Neumayer 2000, 193; Slaski-Tabaczyński 1959, Taf. IV; Herrmann 1985, Taf. 71a; Richthofen 2016, Abb. 1.

která spíše připomíná tzv. agnusky, tedy plastiky zobrazující beránka jako Agnus Dei z mladších depotů (Michnová-Polanský-Tomková-Tymonová 2010, 119-120, obr. 5), jsou solitérní kusy. Pouze rozvržením výzdobného motivu na kaptorze v podobě hřbetů s kulatýma ušima se do skupiny zoomorfních šperků hlásí kaptorgy z depotu z Dzierznici ve Velkopolsku (obr. 12:10; Slaski-Tabaczyński 1959, tab. 4). ${ }^{8}$

\section{Závěr}

Šperky z hrobů 16 a 47 z pohřebiště Triangl potvrzují poznatky dřívějšího bádání o výrobcích pražské dílny a v některých směrech je rozšiřují. Záušnice s trojicí rytířů na koních zůstávají

8 Při hledání možných analogií mě upozornil J. Košta na dosud nepublikovaný nález z Rakvic. Pod inv. č. 54297 je v NM uložena stříbrná záušnice (?), která má podobu jakési kapsle členěné do tř́i částí plastickým ornamentem připomínajícím schematizované zviřecí hřbety. Podle zmínky J. Smolíka byla do muzejní sbírky darována v r. 1888 spolu s několika denáry z depotu z Rakvic, v němž byl nejmladší mincí denár Soběslava I. (Smolík 1889). Jiřímu Koštovi za upozornění a možnost předmět si prohlédnout děkuji. 
solitérem ve svém provedení, celkově je však lze zařadit do variabilního typu zoomorfních, animálních a figurálních záušnic, které nebyly vyráběny jen v pražské dílně. Podobně u kaptorg jako předmětů, z nichž každý je svým výtvarným pojetím originál, je obtížné vést mezi nimi linku prrímé spojitosti, s výjimkou předmětů prokazatelně vyrobených v jedné dílně. Polští archeologové hledali původ kaptorg z pokladů zlomkového stř́bra v karolínském uměleckém řemesle (Duczko 2016, 141, zde starší literatura); ale již H. Kóčka-Krenz připustila české prostřednictví $(1993,87)$, což v obecné rovině jako post-velkomoravský vliv na polský šperk později připustil i W. Duczko (2018). A. Sztyber akcentuje magickou funkci s tím, že bohatí lidé si nechávali vyrobit schránku amuletu z drahého kovu bohatě zdobenou, zatímco chudší se museli spokojit s prostším materiálem včetně dřeva (Sztyber 1999, 285).

Košíčkovité korálky s polokoulemi spojenými meandrovitou páskou jsou ukázkou funkčního použití dříve jen dekorativního motivu. Samotný typ košíčkovitých náušnic je inovativním využitím techniky výroby košičkovitých náušnic veligradského typu, kdy se jednotlivé, patřičně zvětšené košíčky už nenavlékaly napevno na drát náušnice, nýbrž mohly se volně kombinovat do náhrdelníku. Vývoj poté spěl k patentkovitým korálům zdobeným granulací z hrobu 100 z Prahy Lumbeho zahrady, které se použitím granulace sbližují s košíckovitými náušnicemi z depotů z Čistěvsi a Žatce. Depot v Čistěvsi byl uložen do země v 90. letech 10. století (Polanský-Tomková 2006), depot z Žatce je kladen do druhého desetiletí 11. století (Čech 2000, 261-269). Depot z Čistěvsi obsahoval vedle mincí a dalších typů šperků také náušnice se třemi košíčky a náušnice se třemi bubínky navlečenými na oblouku (Polanský-Tomková 2006, obr. 9a-b). K. Tomková zjistila, že košičky jsou sestaveny v moravsko-české tradici z brýlovitě/preclíkovitě stočených dílků z tordovaných drátků, $v$ jejichž spojích jsou osazeny granulky. Naopak náušnice se třemi válcovitými bubínky jsou podle ní importy (Tomková 2006, 106-113). V této souvislosti bych upozornila na změnu schématu náušnice: veligradský šperk má prvořadou osu vertikální - nejen hrozníčky přivěšené k oblouku náušnice svisle, ale i bubínky a košičky jsou uspořádány tak, že svislá osa je delší než vodorovná. Přetrvávající vertikalitu můžeme sledovat ještě u hrozníčkových náušnic s esovitou kličkou typu Jízdárna z pražské dílny přes jakési přechodné schéma, kdy jsou rozměr svislý a vodorovný rovnocenné, jako je tomu na pseudobubínkových náušnicích s polokruhovou destičkou z hrobu 82 v Praze - Lumbeho zahradě (Smetánka-Frolík 2014, 100), až po schéma horizontální u zoomorfních náušnic, které se na Moravě v 9. století nevyskytují. Náušnice se třemi košícky navlečenými na spodním oblouku náušnic, tedy horizontálně, jsou dále doloženy z hrobu 18/1912 ze Žalova (Tomková 2012, 41) a z pokladu ze Žatce (Čech 2000, 262-263). Granule na košíčcích splétaných z tordovaného drátu bývají i na náušnicích z Polska, které jsou ovšem splétány z drátu vedeného smyčkovitě. M. Dekówna je klasifikuje jako, ,zausznice odmiany drugiej" a odmítá jejich původ z veligradského šperku (Dekówna 1992, 101-107, obr. 1, 2). Řazení košíčků či bubínků vedle sebe je typické pro zausznice/náušnice z území Polska (s výjimkami ovlivněnými šperkem veligradského typu, např. ze Zawady Lanckorońskej - Zoll-Adamikowa-Dekówna-Nosek 1999) a Kyjevské Rusi (napřr. Lutovský 1986). Nejstarší polské košíčkovité zausznice/náušnice klade M. Dekówna do druhé poloviny 10. století, avšak již v první polovině 11. století se vyskytují převážně jako zlomky v pokladech, což podle ní znamená, že už vyšly z módy (Dekówna 1992, 100-101). Vedle odlišné technologie vinutí drátu tvořícího košíček argumentuje M. Dekówna proti velkomoravskému původu také velkou časovou mezerou (Dekówna 1992, 111-113); právě činnost pražské klenotnické dílny však tuto mezeru překlenuje.

Klenotníci činní v pražské dílně 10 . století projevili tvůrčího ducha při přepracovávání typů a motivů převzatých ze šperku veligradského typu, obohacovali své výrobky o prvky soudobých módních vlivů a ve druhé polovině 10 . století se jejich tvorba stávala inspirací pro některé šperky vyráběné na územích severních sousedů tehdejšího přemyslovského knížectví.

Příspěvek vznikl v rámci projektu Centra excelence GAČR 14-36938G Středověká populace v centru a na venkově. Archeologie, bioarcheologie a genetika na pohřebištích Pražského hradu, středních a východních Čech. 


\section{Prameny a literatura}

ANOŠKINOVÁ, V., 1995: Identifikácia orientálních motívov ve vel'komoravskom umení na príklade analýzy ornito-animálnej výzdoby - Identification of Oriental motives in the art of Great Moravia on the example of ornito-animal decoration, ARS 2-3, 124-138.

BARČÁKOVÁ, L., 2014: Výroba raně středověkého šperku naleziště v Lumbeho zahradě na Pražském hradě - Production of Early Medieval Jewellery from the Lumbe Gardens Cemetery at the Prague Castle. In: Frolík, J. a kol., Pohřebiště v Lumbeho zahradě na Pražském hradě. Díl II. Studie. Castrum Pragense 12, 311-418. Praha.

ČECH, P., 2000: Der Depotfund von Saaz (Žatec). In: Europas Mitte um 1000. Katalog (Wieczorek, A.Hinz, H.-M., edd.), 261-269. Stuttgart.

DEKÓWNA, M., 1992: Zausznice koszyczkowate - przyczynek do badań nad pochodzeniem wczesnośredniowiecznych ozdób srebrncych występujących na terenie Polski, Archeologia Polski 37, č. $1-2,89-122$.

DOSTÁL, B., 1966: Slovanská pohřebiště ze střední doby hradištní na Moravě - Slawische Begräbnisstätten der mittleren Burgwallzeit in Mähren. Praha.

DUCZKO, W., 2016: Status i magia. Ozdoby elity z Bodzi - Status and Magic. The Personal Ornaments of the Elite from Bodzia. In: Bodzia. Elitarny cmentarz z początków państwa polskiego (Buko, A., ed.), 131-151. Warszawa.

- 2018: Post-wielkomorawski fenomen. Wczsnośredniowieczna sztuka złotnicza w środkowej i wschodniej Europie - Post-Great Moravian Phenomenon. Early Medieval Goldsmithery in Middle and Eastern Europe. In: Inspiracje i funkcje sztuki pradziejowej i wczesnośredniowiecznej (Gediga, B.-Grossman, A.Piotrowski, W., edd.), 535-547. Biskupin - Wrocław.

EISNER, J., 1955: Počátky českého šperku - Načala češskich ukrašenij - Die Anfänge des böhmischen Schmucks, PA XLVI, 215-225.

FIKRLE, M.-FRÁNA, J.-TOMKOVÁ, K., 2012: Raně středověký šperk z pohřebišt' na katastru Žalova z pohledu rentgenové fluorescenční analýzy - Frühmittelalterlicher Schmuck von den Gräberfeldern auf Levý Hradec und seinen Vorfeldern aus der Sicht der Röntgenfluorescenzanalyze. In: Tomková, K. a kol., Levý Hradec v zrcadle archeologických výzkumů. Pohřebiště. Díl I, 321-335. Praha.

FRÁNA, J.-TOMKOVÁ, K., 2005: Raně středověký kovový šperk z pohřebišt' Pražského hradu a jeho předpolí z pohledu rentgenové-fluorescenční analýzy - Frühmittelalterlicher Metallschmuck von den Gräbern der Prager Burg und ihrer Vorfelder aus der Sicht der Röntgenfluorescenz-analyze. In: Pohřbívání na Pražském hradě a jeho předpolích. Díl I.1. Castrum Pragense 7 (Tomková, K., ed.), 311-331. Praha.

FROLÍK, J., 2014: Pohřebiště v Lumbeho zahradě na Pražském hradě, analýza, chronologie, význam - Cemetery in the Lumbe Garden of the Prague Castle. Analysis, Chronology, Significance. In: Frolík, J. a kol., Pohřebiště v Lumbeho zahradě na Pražském hradě. Díl II. Studie. Castrum Pragense 12, 5-116. Praha.

FROLÍK, J.-TOMKOVÁ, K.-ŽEGKLITZ, J., 1988: Výzkum slovanského pohřebiště v jižním křídle Jízdárny Pražského hradu - Erforschung des slawischen Gräberfeldes im Südflügel der Reitschule der Prager Burg, PA LXXIX, 424-455.

FROLÍKOVÁ-KALISZOVÁ, D., 2000: Pokus o analýzu slovanského pohřebiště v Praze-Motole - Versuch einer analyse des slawischen Gräberfelds in Prag-Motol, PA XCI, 201-249.

- 2014: Pohřebiště z 10. století v Praze-Střešovicích - předběžná zpráva - Ein Gräberfeld aus dem 10. Jahrhunderts in Prag-Střešovice - Vorläufiger Bericht, AH 39, 315-329.

- 2014a: Ein Gräberfeld des 10. Jahrhunderts aus dem Umfeld der Prager Burg. In: Die frühen Slawen - von der Expansion zu gentes und nationes. Beiträge zur Ur- und Frühgeschichte Mitteleuropas 81/2 (Biermann, F.-Kersting, T.-Klammt, A., edd.), 101-111. Langenweissbach.

FROLÍKOVÁ-KALISZOVÁ, D.-KAUPOVÁ, S., 2018: Populace pohřbená na pohřebišti Triangl v Praze-Střešovicích z hlediska rekonstrukce stravy - Die auf dem Gräberfeld Triangel in Prag-Střešovice bestattete Population im Hinblick auf die Rekonstruktion der Ernährung, AH 43, 7-19.

FROLÍKOVÁ, D.-OTTENWELTER, E.-BARČÁKOVÁ, L., v tisku: Child burial with a necklace from the Triangle cemetery in Prague-Střešovice. 
GALUŠKA, L., 1989: Výrobní areál velkomoravských klenotníků ze starého Města - Uherského Hradiště Das Erzeugungsareal des grossmährischen Juweliere aus Staré Město - Uherské Hradiště, PA LXXX, 405-454.

- 2013: Hledání původu. Od avarských bronzů ke zlatu Velké Moravy. Search for the origin. From Avar bronze items Great Moravian gold. Brno.

GUPIENIEC, A.-KIERSNOWSCY, T. i R., 1965: Wczesnośredniowieczne skarby srebrne z Polski środkowej, Mazowsza i Podlasia. Wrocław - Warszawa - Kraków.

HAISIG, M.-KIERSNOWSKI, R.-REYMAN, J., 1966: Wczesnośredniowieczne skarby srebrne z Małopolski, Śląska, Warmii i Mazur - Les trésors d'argent du hout moyen âge de la Petite Pologne, de la Silésie, de Warmia et Mazury. Wrocław - Warszawa - Kraków.

HASIL, J.-OTTENWELTER, E.-BARČÁKOVÁ, L., 2019: Dubious Early Medieval Jewels from Matzhausen (Bavaria): New Material and Technological Investigations. Studies in Conservations. https://doi.org/10.1080/00393630.2019.1677082

HERRMANN, J., 1985: Die Slawen in Deutschland. Berlin.

HRUBÝ, V., 1955: Staré Město - velkomoravské pohřebiště Na Valách - Stare Město, Velikomoravskij mogilnik „Na Valach“ - Staré Město, Die grossmährische Begräbnisstätte „Na Valách“. Praha.

HUML, V.-STAREC, P., 1994: Raně středověké pohřebiště na Václavském náměstí čp. 784 v Praze - Das frühmittelalterliche Gräberfeld auf dem Wenzelsplatz in Prag, AR XLVI, 454-463.

CHARVÁT, P., 2010: Slyšte volání muezzinovo. České země a arabský svět ve starším středověku (do roku 1300) - Hark the call of the mu'azzin: Czech-speaking lands and the Arab world in the earlier Middle Ages (up to 1300 A. D.). Plzeň.

CHORVÁTOVÁ, H., 2009: Kultúrno-historický význam gombíkov, Studia mediaevalia Bohemica 1, 7-19.

KABÁT, J., 1950: Slovanské nálezy na Př́bramsku - Slavjanskije nachodki na Pržibramske - Trouvailles slaves de la région de Př́ibram, AR II, 75-76.

KLANICA, Z., 1970: Velkomoravský gombík - Das grossmährische „Gombík“ (Kugelknopf), AR XXII, 421-446.

- 1974: Práce klenotníků na slovanských hradištích - Die Arbeit von Juwelieren auf den slawischen Burgwällen. Studie Archeologického ústavu ČSAV v Brně II/6. Brno.

- 1991: K interpretaci motivu ptáčka na jihomoravských památkách 8.-9. století. In: XX. Mikulovské sympozium, 181-193. Brno.

KLANICA, Z.-KAVÁNOVÁ, B.-KOUŘIL, P.-UNGERMAN, Š., 2019: Mikulčice - Die Nekropole an der dreischiffigen Basilika. Brno.

KÓČKA-KRENZ, H., 1993: Biżuteria północno-zachodnio-słowiańska we wczesnym średniowieczu - The north-western-Slavonic jewellery in the Early Middle Ages. Poznań.

LUTOVSKÝ, M., 1986: Raně středověké šperky ruského původu v Čechách - Frühmittelalterliche Schmuckstücke russischer Provenienz in Böhmen, ČNM A CLV, 1-12.

MICHNOVÁ, V.-POLANSKÝ, L.-TOMKOVÁ, K.-TYMONOVÁ, M., 2010: Komárovský poklad. Revize dochované části torza depotu - The Komárov hoard. Description and the preserved part of the hoard revised, Numismatické listy 65, 98-126.

MUSIANOWICZ, K., 1948-1949: Kablączky śkroniowe - próba typologii i chronologii, Świątowit 20, $115-232$.

NEUMAYER, H., 2000: Panzerreiterstatuette. In: Europas Mitte um 1000 - Katalog (Wieczorek, A.Hinz, H.-M., edd.), 165. Stuttgart.

-2000a: Das Grab von Matzhausen. In: Europas Mitte um 1000 - Katalog (Wieczorek, A.-Hinz, H. M., edd.), 192-193. Stuttgart.

OTTENWELTER, E., 2018: Praha-Střešovice (Triangl), hrob 47. Konzervátorská a restaurátorská zpráva, ulož. v archivu nálezových zpráv ARÚ Praha, č. TP-2018-50027.

OTTENWELTER, E.-DĚD, J.-BARČÁKOVÁ, L., 2014: Technical study of jewellery from the „Lumbe garden“ cemetery at Prague Castle - Technologický průzkum šperků z pohřebiště v Lumbeho zahradě. In: Frolík, J. a kol., Pohřebiště v Lumbeho zahradě na Pražském hradě. Díl II. Studie. Castrum Pragense 12, 163-310. Praha. 
POLANSKÝ, L.-TOMKOVÁ, K., 2006: Hromadný nález denárů a šperků z Čistěvsi. Revize popisu a dochované části depotu - A group find of denarii and jewelry from Čistěves. Description revised, preserved parts of the group find presented, Numismatický sborník 21, 83-121.

POULÍK, J., 1948: Staroslovanská Morava. Praha.

- 1975: Mikulčice. Sídlo a pevnost knížat velkomoravských - Mikulčice - Rezidencja i krepost’ velikomoravskich kňjazej - Mikulčice - Sitz und Feste der grossmährischen Fürsten. Praha.

PRINCOVÁ-JUSTOVÁ, J., 1997: Tisíciletá Libice - Ústředí slavníkovské domény a pravděpodobné rodiště svatého Vojtěcha. In: Śląska i Czechy a kultura wielkomorawska (Wachowski, K., ed.), $103-112$. Wrocław.

PROFANTOVÁ, N., 1996: To central Asia and beyond - Oriental motifs of the late Avar and Great Moravian epochs (8th-9th century). In: Ibrahim ibn Ya'qub at-Turtushi: Christianity, Islam and Judaism, Meet in East-Central Europe, c. 800-1 300 A. D. (Charvát, P.-Prosecký, J., edd.), 26-36. Praha.

- 2000: Stará Kourrim, Bez. Kolín. Grab 106b (Tschechien). In: Europas Mitte um 1000 - Katalog (Wieczorek, A.-Hinz, H.-M., edd.), 215-218. Stuttgart.

- 2011: Pohřebiště Klecany II. In: Profantová, N. a kol., Klecany. Raně středověká pohřebiště. 1. svazek, 137-210. Praha.

- 2013: Ke změnám ve vývoji hmotné kultury 10. století - Zu den Veränderungen in der Entwicklung der Sachkultur des 10. Jahrhunderts in Böhmen, AH 38, 27-44.

- 2013a: Archeologický doklad kulturních styků Bavorska a Čech v 10. století - Archaeological Evidence of Cultural Contacts between Bavaria and Bohemia in the 10th Century, ASČ 17, 207-214.

PROFANTOVÁ, N.-DANĚČEK, D., 2017: Nová stř́ibrná kaptorga ze středních Čech v souvislosti s konkrétním výrobním okruhem (?) v Praze - New silver Kaptorga from Middle Bohemia in response to an identified Production Centre in Prague (?), Slavia Antiqua 58, 91-113.

PROFANTOVÁ, N.-FRÁNA, J., 2003: Příspěvek ke studiu šperkařství v raném středověku v Čechách a na Moravě - A contribution to the study of jewellery-making in the Early Middle Ages in Bohemia and Moravia, AR LV, 47-58.

PROFANTOVÁ, N.-MILITKÝ, J., 2000: Das „Fürstinnengrab“von Želénky - Zwei Kugelknöpfe. In: Europas Mitte um 1000 - Katalog (Wieczorek, A.-Hinz, H.-M., edd.), 188-189. Stuttgart.

PROFANTOVÁ, N.-ŠILHOVÁ, A., 2010: Raně středověké kaptorgy v Čechách. Analýza nálezu z hrobu č. 22 na pohřebišti Klecany II - Frühmittelalterliche Kaptorgen in Böhmen. Ananlyse eines Fundes aus Grab Nr. 22 auf dem Gräberfeld Klecany II, PA CI, 283-310.

PROFANTOVÁ, N.-ŠPAČEK, J.-NOVOTNÁ, M., 2011: Nové poznatky o výrobě a obsahu kaptorg na základě studia hrobů ze Zelenče a Čelákovic, okr. Praha-východ - New Knowledge about the Manufacture and Contents of Kaptorgas based on the Study of Graves from Zeleneč and Čelákovice, Prague-East District, ASČ 15, 539-552.

RICHTHOFEN, J. von, 2016: Der Hacksilberschatz von Meschwitz und die Oberlausitzer Silberschätze um 1000. In: Die frühen Slawen - von der Expansion zu gentes und nationes. Beiträge zur Ur- und Frühgeschichte Mitteleuropas 81/2 (Biermann, F.-Kersting, T.-Klammt, A., edd.), 123-134. Langenweissbach.

SCHULZE-DÖRRLAMM, M., 1992: Schmuck der spätottonischen bis frühsalischen Zeit. In: Das Reich der Salier 1024-1125. Katalog zur Ausstellung (Weinfurter, S., ed.), 110-176. Sigmaringen.

SKLENÁŘ, K.-SLÁMA, J., 1976: Nález slovanských kostrových hrobů v bývalé Královské zahradě Pražského hradu v roce 1837 - Die Entdeckung slawischer Körpergräber im Königlichen Garten der Prager Burg im Jahre 1837, AR XXVIII, 659-665.

SLASKI, J.-TABACZYŃSKI, S., 1959: Wczesnośredniowieczne skarby srebrne Wielkopolski - Les trésors d'argent du hout moyen âge en Grande Pologne. Warszawa - Wrocław.

SMETÁNKA, Z., 1994: Př́spěvek ke studiu karolinského vlivu na velkomoravský šperk v Čechách a na Moravě - The Carolingian Influence on the Great Moravian Jewellery in Bohemia and Moravia, Praehistorica 21 - Varia Archaeologica 6, 105-115.

SMETÁNKA, Z.-FROLÍK, J., 2014: Pohřebiště v Lumbeho zahradě na Pražském hradě - Katalog. In: Pohřebiště v Lumbeho zahradě na Pražském hradě. Díl I. Katalog (Frolík, J.-Smetánka, Z., edd.). Castrum Pragense 12. Praha. 
SMETÁNKA, Z.-STAŇA, Č., 1996: Velká Morava a Praha (Rentgenfluorescenční analýza zlatých šperků z Velké Moravy a jejich vztah k Pražskému hradu). In: Słowiańszczyzna w Europie (Kurnatowska, Z., ed.), 137-142. Wrocław.

SMETÁNKA, Z.-ŠTVERÁK, B., 1992: X-Ray fluorescent analysis of gold and gilded jewels from the cemetery in Lumbe Gardens at Prague Castle. Preliminary report - Rentgenfluorescenční analýza zlatých a zlacených šperků z pohřebiště v Lumbeho zahradě na Pražském hradě (Předběžná zpráva), AR XLIV, $418-430$.

SMOLÍK, J., 1889: Zprávy a drobnosti, část III - Mince, PA XIV, 662.

SPAZIER, I.-SEIDL, C.-SCHENK, E., 2015: Die Gräbergruppe von Oberwellenborn, Lkr. Saalfeld-Rudolstadt, im Vergleich zu anderen slawischen Gräberfeldern in Thüringen - Aussagen zur historischen Schmuckherstellung, Alt-Thüringen 44, 167-208.

STAŇA, Č., 1995: Příspěvek k poznání horizontu velkomoravského šperku - Beitrag zur Erkenntnis des Veligrader Schmucks-Horizonts, SPFFBU E 40, 37-45.

STRÁNSKÁ, P., 2014: Antropologická analýza lidských kostrových pozůstatků z raně stř̌edověkého pohřebiště v Praze 6 - Střešovicích, poloha Triangl - Anthropologische Analyse menschlicher Skelettüberreste von dem frühmittelalterlichen Gräberfeld in Prag-Střešovice, Lage Triangl, AH 39, 331-345.

SVĚTLÍK, I.-ŠNEBERGER, J., 2020: Výsledky radiouhlíkového datování. Protokol uložený v archivu středověkého oddělení - výzkum Pražského hradu ARÚ Praha.

SZTYBER, A., 1999: Kaptorgi. Przykład kunsztu wczesnośredniowiecznego złotnictwa, Alma Mater. Miesięcznik Uniwersytetu Jagiellońskiego 46, 283-286.

ŠOLLE, M., 1960: K podunajskému proudu v Čechách v době hradištní - Zum Donauländischen Zustrom in Böhmen in der Burgwallzeit, Vznik a počátky Slovanů 3, 255-269.

- 1966: Stará Kouřim a projevy velkomoravské hmotné kultury v Čechách - Alt Kouřim und großmährische Kultur in Böhmen. Praha.

ŠTEFAN, I., 2005: Kaptorgy: pokus o kontextuální analýzu - Die Kaptorgen: ein Versuch um die kontextuelle Analyse, Studia Mediaevalia Pragensia 5, 21-60.

TOMKOVÁ, K., 2005: Hmotná kultura raně středověkých pohřebišt' Pražského hradu a jeho předpolí - Das Grabinventar auf den frühmittelalteerlichen Gräberfeldern der Prager Burg auf ihren Vorfeldern. In: Pohřbívání na Pražském hradě a jeho předpolích. Díl I.1. Castrum Pragense 7, 217-304. Praha.

- 2006: Raně středověká pohřebiště na předpolí Pražského hradu I. Frühmittelalterliche Gräberfelder auf dem Vorfeld der Prager Burg I. In: Pohřbívání na Pražském hradě a jeho předpolích. Díl I.2. Castrum Pragense 7, 5-128. Praha.

- 2008: Emma a šperk její doby v kontextu vývoje raně středověkého šperku. In: Emma Regina - Civitas Melnic (Kilián, J.-Polanský, L., edd.), 89-105. Mělník - Praha.

- 2011: Der Kulturwandel des 10. Jahrhunderts in Böhmen aus archäologischer Sicht. In: Der Wandel um 1000 Beiträge zur Ur- und Frühgeschichte Mitteleuropas 60 (Biermann, F.-Kersting, T.-Klammt, A., edd.), 199-208. Langenweissbach.

- 2012: Pohřebiště na Levém Hradci a jeho předpolí. Katalog - Die Gräberfelder in Levý Hradec und auf seinen Vorfeldern. Katalog. In: K. Tomková a kol., Levý Hradec v zrcadle archeologických výzkumů. Pohřebiště. Díl I, 7-272. Praha.

TOMKOVÁ, K.-FROLÍK, J., 2005: Topografie pohřbívání v areálu Pražského hradu a na jeho předpolích Die Topographie der Bestattungen im Areal der Prager Burg und auf ihren Vorfelder. In: Pohřbívání na Pražském hradě a jeho předpolích. Díl I.1. Castrum Pragense 7, 7-24. Praha.

UNGERMAN, Š., 2005: Ženský šperk staršího velkomoravského horizontu - Frauenschmuck des älteren grossmährischen Horizonts, AR LVII, 707-749.

- 2007: Raně středověké pohřebiště v Dolních Věstonicích - Na Pískách. Disertační práce, FF MU, Brno. Dostupné z: http://is.muni.cz/th/18484/ff_d/.

ZOLL-ADAMIKOWA, H.-DEKÓWNA, M.-NOSEK, E. M., 1999: The early Mediaeval Hoard from Zawada Lanckorońska (Upper Vistula River) - Wczesnośredniowieczny skarb z Zawady Lanckorońskiej (dorzecze górnej Wisly). Warszawa. 


\section{Zusammenfassung}

\section{Ein neuer Beitrag zur Schmuckproduktion der Prager Werkstätte}

In den letzten Jahrzehnten nehmen die Belege für die Herstellung einer charakteristischen Gruppe Schmuck zu, die auf den Gräberfeldern in Prag und Umgebung entdeckt wurden und als Erzeugnisse einer Prager Werkstatt angesehen werden (Tomková 2011). In den Gräbern 16 und 47 des Gräberfeldes Triangel in Prag-Střešovice (Frolíková-Kaliszová 2014a) wurden Schmuckgarnituren gefunden, die in dieser Werkstatt hergestellt worden sind: in Kindergrab 16 eine Halskette bestehend aus drei Typen silberner körbchenartiger Perlen mit einer Kaptorge (Abb. 3-5), in Frauengrab 47 eine Halskette aus Bernstein- und Glasperlen und eine Garnitur von 16 Silberschläfenringen mit Ösen und Reste von 3 Schläfenringen in Form von drei Reitern zu Pferde (Abb. 6-8). Die Kombination der Schläfenringe mit Ösen und Bernsteinperlen datiert das Grab in das zweite Drittel des 10. Jahrhunderts, was mit der aus dem Kollagen eines Wadenbeins ermittelten AMS $C^{14}$ Datierung korrespondiert, die mit einer Wahrscheinlichkeit von 83,2 \% in das Zeitintervall 860-972 fällt. Bei Grab 16 lieferte die AMS C ${ }^{14}$ Datierung des vom Schädelknochen stammenden Kollagens mit einer Wahrscheinlichkeit von 95,4 \% ein Datum in dem breiten Zeitintervall 774-950 AD, davon mit einer Wahrscheinlichkeit von 12,6 \% im engeren Zeitintervall 921-950 (Abb. 9).

Von aus Drahtringen oder -brezeln in der Technologie des sog. Veligrader Schmucks geflochtenen Metallperlen gibt es vier Typen: eine Perle aus lediglich zusammengelöteten Halbkugeln, mit Öffnungen, die mit glattem oder tordiertem Draht umsäumt sind (Abb. 10:1); ein Körbchen aus mit tordiertem Draht verbundenen Halbkugeln (Abb. 10:2); eine Perle aus mit einem meanderförmigen Band verbundenen Halbkugeln (Abb. 10:3) und eine „druckknopfartige“ Perle aus Grab 100 vom Gräberfeld im Lumbe-Park der Prager Burg (Abb. 10:4). Unter den Kaptorgen, die als Amuletthüllen jeweils ein originales, für einen konkreten Kunden hergestelltes Exemplar darstellen, tut sich eine in gleicher Weise hergestellte Kaptorgengruppe hervor, die auf der Vorderseite mit einem gehämmerten und geritzen Dekor auf punziertem Hintergrund verziert sind und eine aufsetzbare, für gewöhnlich flechtbandverzierte Verschlusskappe besitzen. Sie wurden auf Gräberfeldern in Prag oder dessen naher Umgebung gefunden (Abb. 11) und stammen demnach offenbar alle aus der Prager Werkstatt.

Das meanderförmige Band ist ein Strukturelement, das in Form von aus großmährischen Goldschmiedewerkstätten stammendem Schmuck aus der karolingischen Schmuckkunst übernommen wurde, dessen Verwendung als Verbindungselement jedoch eine Innovation der Prager Werkstatt ist. Ein originelles Schmuckstück ist der Schläfenring mit drei Reitern/Rittern, dessen nächsten Analogien Schläfenringe aus den relativ entfernten Fundstellen von Lovosice und Hořejany sind (Abb. 12:1, 2). Aus der Prager Werkstatt stammen die bekannten zoomorphen Ohrringe aus Grab 16 im Prager Lumbe-Park (Abb. 12:3). Gebräuchlicher ist die Verwendung von Pferdebüsten auf Kaptorgen (Abb. 12:4, 7), die in ein symbolhaftes Ornament übergehen (Abb. 12:10). In späteren Hacksilberdepots tauchen zoomorphe Ohrringe auf (Abb. 12:5, 6), deren Gestaltung wohl auf der Gestaltung von aus Niedermünster stammenden Ohrringen basieren (Abb. 12:8). Eine andere Darstellungsform von Tieren sehen wir auf einer Kleinplastik aus Matzhausen (Abb. 12:9).

Die Produktion der Prager Werkstatt war eine schöpferische Synthese des Schmucks des sog. Veligrader Typs und von Impulsen zeitgenössischer Modeeinflüsse, die im Laufe des 10. Jahrhunderts eigene Typen und Varianten von vornehmlich Silberschmuck bildete und auf diese Weise eine natürliche Verbindung zu einigen Schmucktypen und -motiven von aus der zweiten Hälfte des 10. und 11. Jahrhunderts und aus dem Gebiet Polens und des Elblands stammenden Hacksilberschätzen und Gräberfeldern darstellt.

PhDr. Drahomíra Frolíková-Kaliszová, Ph.D., Archeologický ústav AV ČR, Praha, v. v. i., Letenská 4, 11801 Praha 1, Česká republika,frolikova@arup.cas.cz 
Toto dílo lze užít v souladu s licenčními podmínkami Creative Commons BY-NC-ND 4.0 International (https://creativecommons.org/licenses/by-nc-nd/4.0/legalcode). Uvedené se nevztahuje na díla či prvky (např. obrazovou či fotografickou dokumentaci), které jsou v díle užity na základě smluvní licence nebo výjimky či omezení príslušných práv. 
